\title{
The role of non-invasive devices for the telemonitoring of heart failure patients
}

\author{
A. Faragli 1,2,3,5 - D. Abawi ${ }^{1}$ - C. Quinn ${ }^{4} \cdot$ M. Cvetkovic $^{1} \cdot$ T. Schlabs $^{1}$ • E. Tahirovic ${ }^{1}$ - H.-D. Düngen ${ }^{1,3} \cdot$ B. Pieske ${ }^{1,2,3,5}$. \\ S. Kelle ${ }^{1,2,3,5} \cdot$ F. Edelmann ${ }^{1,2,3} \cdot$ Alessio Alogna ${ }^{1,2,3}$
}

Published online: 27 April 2020

(C) The Author(s) 2020

\begin{abstract}
Heart failure (HF) patients represent one of the most prevalent as well as one of the most fragile population encountered in the cardiology and internal medicine departments nowadays. Estimated to account for around 26 million people worldwide, diagnosed patients present a poor prognosis and quality of life with a clinical history accompanied by repeated hospital admissions caused by an exacerbation of their chronic condition. The frequent hospitalizations and the extended hospital stays mean an extremely high economic burden for healthcare institutions. Meanwhile, the number of chronically diseased and elderly patients is continuously rising, and a lack of specialized physicians is evident. To cope with this health emergency, more efficient strategies for patient management, more accurate diagnostic tools, and more efficient preventive plans are needed. In recent years, telemonitoring has been introduced as the potential answer to solve such needs. Different methodologies and devices have been progressively investigated for effective home monitoring of cardiologic patients. Invasive hemodynamic devices, such as CardioMEMS $^{\mathrm{TM}}$, have been demonstrated to be reducing hospitalizations and mortality, but their use is however restricted to limited cases. The role of external non-invasive devices for remote patient monitoring, instead, is yet to be clarified. In this review, we summarized the most relevant studies and devices that, by utilizing non-invasive telemonitoring, demonstrated whether beneficial effects in the management of HF patients were effective.
\end{abstract}

Keywords Heart failure $\cdot$ Telemonitoring $\cdot$ Non-invasive $\cdot$ Medical devices

\section{Background}

Heart failure (HF) is a clinical syndrome characterized by symptoms such as breathlessness, ankle swelling, and fatigue that may be accompanied by signs such as elevated jugular

Alessio Alogna

alessio.alogna@charite.de

1 Department of Internal Medicine and Cardiology Campus Virchow-Klinikum, Charité - Universitätsmedizin Berlin, Augustenburgerplatz 1, 13353 Berlin, Germany

2 Berlin Institute of Health (BIH), Berlin, Germany

3 DZHK (German Centre for Cardiovascular Research), Partner Site Berlin, Berlin, Germany

4 Department of Biological Sciences, Rensselaer Polytechnic Institute, 110 Eighth Street, Troy, NY, USA

5 Department of Internal Medicine/Cardiology, Deutsches Herzzentrum Berlin, Augustenburger Platz 1, 13353 Berlin, Germany venous pressure, pulmonary crackles, and peripheral edema $[1,2]$. The current definition of HF, as stated by the most recent European Society of Cardiology guidelines, restricts itself to stages at which clinical symptoms are apparent [1, 2]. However, even in the asymptomatic phase, patients may experience already structural or functional cardiac abnormalities (systolic or diastolic left ventricular (LV) dysfunction) that can lead to overt HF $[1,2]$. The estimated absolute number of people suffering from HF in the world approaches 26 million, and this widespread pathology can be encountered nowadays both in developed and developing countries [3]. Chronic heart failure (CHF) patients represent one of the leading population at risk of frequent hospitalizations and poor life expectancy, and indeed only $10 \%$ of these patients are alive at 10 years from diagnosis $[4,5]$. Annually, 1 million patients are hospitalized with a primary diagnosis of $\mathrm{HF}$, accounting for a total Medicare expenditure exceeding $\$ 17$ billion in the USA every year [6]. Despite dramatic improvements in outcomes with medical therapy, admission rates following hospitalizations remain high, with $20-30 \%$ of the patients readmitted 
after 30 days and $>50 \%$ of them readmitted within 6 months after discharge [7, 8]. Because of the high rate of re-hospitalizations, the high mortality, the poor quality of life, and the substantial cost sustained by the national healthcare system, much effort has been made to identify the parameters and risk factors that can help in the prediction and prevention of decompensation events and unnecessary hospitalizations $[9,10]$. Several physiological indices of HF severity anticipate serious adverse events such as elevated filling pressures, jugular venous pressure, orthopnea, and echocardiographic filling patterns hospitalizations $[9,10]$. Levels of cardiac biomarkers, including natriuretic peptides and cardiac troponins, may also anticipate the readmission risk, particularly if they remain high at hospital discharge [11, 12]. Indicators of neurohormonal activation, including higher levels of circulating catecholamines and renin-angiotensin system metabolites or lower levels of serum sodium, can also identify patients at risk [13, 14]. Increasing diuretic requirements or intolerance of neurohormonal antagonists because of hypotension or renal dysfunction are likely indicators of disease progression and represent an indicator of worsening clinical outcomes [15].

Moreover, the increased burden of atrial or ventricular arrhythmias, the decrease in heart rate variability, and the development of changes in the electrocardiographic traces have been identified as predictors of decompensation events [16-18]. All these parameters, usually investigated in the hospital, are however difficult to obtain when the patients are at home [16-18]. The primary unmet need is indeed the lack of an appropriate and consistent way to predict the decompensation of patients when they are outside the hospital [16-18].

In the recent 10 years, telemedicine, telemonitoring, Mobile Health (mHealth), and Electronic Health (eHealth) have gradually entered the panorama of clinical medicine $[19,20]$. The history of telemedicine had started when blood glucose meters, Holter monitoring, event recorders, and 24-h blood pressure monitoring were introduced to the clinical management of patients [19, 20]. It soon became apparent that monitoring patients' parameters outside the hospital could be a useful way to prevent the occurrence of cardiac decompensation events, especially in a population at risk, such as the one of HF patients [21,22]. Thanks to the advances in technology and in device miniaturization, a de-medicalization of the data has been achieved [21,22]. These advances brought a revolutionary change in the final data users, who have eventually become the patients themselves [21, 22]. Nowadays, this is defined as telemonitoring, home monitoring, or remote patient monitoring (RPM). Telemonitoring consists of either a continuous or sporadic monitoring that can be either dependent on the patients' action or completely independent and automated $[21,22]$. The first non-invasive telemedical systems enabled the transfer of physiological data and parameters to the telemedical centers for data integration (e.g., body weight, heart rate, blood pressure, body temperature) by collecting data indirectly via phone calls to the patients [21-23]. Nowadays, more advanced non-invasive systems are able to measure and transfer data measured non-invasively on electrocardiographic (ECG) tracings, oxygen saturation, blood pressure, and physical activity (e.g., pedometer) [24], or invasively, through implantable devices, enabling the transfer of variables such as impedance analysis and pulmonary artery or left atrial pressures $[25,26]$. Telemonitoring can also be divided into active and passive telemonitoring. While passive telemonitoring is typical for invasive implantable devices sending either sporadically or continuously data to the receiving physician, active telemonitoring via non-invasive devices involves an action (e.g., a video call) or a self-measurement (e.g., blood pressure measurement) by the patients themselves. The role of implantable telemonitoring devices for multi-parameters [25] or cardiac hemodynamic activity monitoring [27] has been recently established as an effective way to prevent frequent hospitalizations [28]. The role of noninvasive methods for the remote monitoring of HF patients, instead, is still under debate $[29,30]$. During the past decade, different studies tried to assess if telemedical interventions and telemonitoring programs would be able to affect mortality and re-hospitalizations of HF patients. Some of the most relevant ones were summarized in Table 1. In this review, we will focus in specific on the role of different non-invasive methods or devices for the remote monitoring of HF patients.

\section{Telephone support}

Different ways of remote monitoring HF patients were investigated in the past, and one of the most studied methods involves regular telephone support to monitor symptoms, changes in body weight, and the psychological status of the patients known as telephone support [22, 31, 32]. The DIAL trial, published in 2005, was one of the first randomized trials analyzing the role of telephone intervention against usual care in 1518 outpatients with stable chronic heart failure and optimal drug treatment. This preliminary study was shown to be effective in reducing admissions to hospital for heart failure. In 2010, Ferrante et al. performed an extended follow-up of the DIAL trial and demonstrated that regular phone intervention could improve adherence on diet, weight control, and medications [22]. One year after the intervention, a reduction of $19 \%$ for all-cause mortality and all-cause hospitalizations was observed [22]. However, that same year, the group of Chaudry et al. was not able to confirm any beneficial effects of remote telemonitoring (defined as daily calls performed to assess the patient's health status, symptoms, and changes in body weight measurement) over standard care [31]. The study's primary endpoint was readmission for any reason or death from any cause within 180 days after enrollment [31]. Secondary endpoints included hospitalizations for HF, number of days in the hospital, and number of all-cause 
Table 1 Overview of the most representative clinical studies analyzing non-invasive remote patient monitoring devices

\begin{tabular}{|c|c|c|c|c|c|c|c|}
\hline Author & Year & $\begin{array}{l}\text { Type of the } \\
\text { study }\end{array}$ & $\begin{array}{l}\text { Number } \\
\text { of } \\
\text { patients }\end{array}$ & Endpoints & Method studied & Devices used in study & Results \\
\hline $\begin{array}{l}\text { Cleland- } \\
\text { TEN-HMS }\end{array}$ & 2005 & $\begin{array}{l}\text { Interventional } \\
\text { study }\end{array}$ & 426 & $\begin{array}{l}\text { All-cause mortality or } \\
\text { re-hospitalizations for } \\
\text { any cause }\end{array}$ & $\begin{array}{l}\text { Structured telephone } \\
\text { support or } \\
\text { non-invasive } \\
\text { home } \\
\text { telemonitoring }\end{array}$ & $\begin{array}{l}\text {-Telephone } \\
\text {-ECG } \\
\text {-Weight scale } \\
\text {-Blood pressure } \\
\quad \text { monitor }\end{array}$ & $\begin{array}{l}\text { BENEFICIAL } \\
\text { EFFECTS } \\
\text { Lower rate of all-cause } \\
\text { mortality }\end{array}$ \\
\hline Klersy & 2009 & Metanalysis & 8612 & $\begin{array}{l}\text { All-cause mortality, } \\
\text { hospitalization for any } \\
\text { cause or hospitalization } \\
\text { for HF }\end{array}$ & $\begin{array}{l}\text { Structured } \\
\text { telephone } \\
\text { support }\end{array}$ & $\begin{array}{l}\text {-Telephone } \\
\text {-ECG }\end{array}$ & $\begin{array}{l}\text { BENEFICIAL } \\
\text { EFFECTS } \\
\text { Lower rate of all-cause } \\
\text { mortality, hospitaliza- } \\
\text { tions and hospitaliza- } \\
\text { tions for HF }\end{array}$ \\
\hline Chaudry & 2010 & $\begin{array}{l}\text { Interventional } \\
\text { study }\end{array}$ & 1653 & $\begin{array}{l}\text { All-cause mortality or } \\
\text { re-hospitalizations for } \\
\text { any cause }\end{array}$ & $\begin{array}{l}\text { Structured } \\
\quad \text { telephone } \\
\text { support }\end{array}$ & $\begin{array}{l}\text {-Telephone } \\
\text {-Weight scale }\end{array}$ & $\begin{array}{l}\text { NO BENEFICIAL } \\
\text { EFFECTS } \\
\text { No differences between } \\
\text { the interventional } \\
\text { group and the usual } \\
\text { care one }\end{array}$ \\
\hline $\begin{array}{l}\text { Ferrante- } \\
\text { DIAL HF }\end{array}$ & 2010 & $\begin{array}{l}\text { Interventional } \\
\text { study }\end{array}$ & 1518 & $\begin{array}{l}\text { All-cause mortality or } \\
\text { hospital admissions } \\
1 \text { year after } \\
\text { randomization }\end{array}$ & $\begin{array}{l}\text { Structured } \\
\text { telephone } \\
\text { support }\end{array}$ & $\begin{array}{l}\text {-Telephone } \\
\text {-Weight scale } \\
\text {-Blood pressure } \\
\quad \text { monitor }\end{array}$ & $\begin{array}{l}\text { BENEFICIAL } \\
\text { EFFECTS } \\
\text { Lower rate of all-cause } \\
\text { mortality and hospi- } \\
\text { talizations for HF }\end{array}$ \\
\hline $\begin{array}{l}\text { Koehler- } \\
\text { TIM-HF }\end{array}$ & 2011 & $\begin{array}{l}\text { Interventional } \\
\text { study }\end{array}$ & 710 & $\begin{array}{l}\text { All-cause mortality or } \\
\text { re-hospitalizations for } \\
\text { HF }\end{array}$ & $\begin{array}{l}\text { Non-invasive home } \\
\text { telemonitoring }\end{array}$ & $\begin{array}{l}\text {-Mobile phones } \\
\text {-ECG } \\
\text {-Weight scale } \\
\text {-Blood pressure } \\
\text { monitor } \\
\text {-Pulse/oximeter }\end{array}$ & $\begin{array}{l}\text { NO BENEFICIAL } \\
\text { EFFECTS } \\
\text { No differences between } \\
\text { the interventional } \\
\text { group and the usual } \\
\text { care one }\end{array}$ \\
\hline $\begin{array}{l}\text { Anand- } \\
\text { MUSIC }\end{array}$ & 2012 & $\begin{array}{l}\text { Interventional } \\
\text { study }\end{array}$ & 543 & $\begin{array}{l}\text { An HF decompensation } \\
\text { prediction algorithm } \\
\text { with } 63 \% \text { sensitivity, } \\
92 \% \text { specificity, and a } \\
\text { false positive rate of } \\
0.9 \text { per patient-year }\end{array}$ & $\begin{array}{l}\text { Bioimpedance } \\
\text { monitoring }\end{array}$ & $\begin{array}{l}\text {-External multi-sensor } \\
\text { monitoring system }\end{array}$ & $\begin{array}{l}\text { BENEFICIAL } \\
\text { EFFECTS } \\
\text { An HF decompensation } \\
\text { prediction algorithm } \\
\text { was developed with } \\
\text { sufficient sensitivity } \\
\text { and specificity } \\
\text { percentages }\end{array}$ \\
\hline $\begin{array}{l}\text { Angermann- } \\
\text { INH study }\end{array}$ & 2012 & $\begin{array}{l}\text { Interventional } \\
\text { study }\end{array}$ & 1007 & $\begin{array}{l}\text { Time to death or } \\
\text { re-hospitalization, HF } \\
\text { symptoms and quality } \\
\text { of life }\end{array}$ & $\begin{array}{l}\text { Structured } \\
\text { telephone } \\
\text { support and } \\
\text { education }\end{array}$ & $\begin{array}{l}\text {-Telephone } \\
\text {-ECG } \\
\text {-Weight scale } \\
\text {-Blood pressure } \\
\quad \text { monitor }\end{array}$ & $\begin{array}{l}\text { BENEFICIAL } \\
\text { EFFECTS } \\
\text { Decreased mortality risk } \\
\text { and increased quality } \\
\text { of life }\end{array}$ \\
\hline $\begin{array}{c}\text { Dovancescu- } \\
\text { SENTINE- } \\
\text { L-HF }\end{array}$ & 2015 & $\begin{array}{l}\text { Interventional } \\
\text { study }\end{array}$ & 180 & $\begin{array}{l}\text { Unplanned HF-related } \\
\text { re-hospitalization, HF } \\
\text { worsening, major ad- } \\
\text { verse cardiac events, } \\
\text { emergency department } \\
\text { visits, all-cause re-- } \\
\text { hospitalization, and } \\
\text { death }\end{array}$ & $\begin{array}{l}\text { Bioimpedance } \\
\text { monitoring }\end{array}$ & $\begin{array}{l}\text {-A transthoracic } \\
\text { bioimpedance vest } \\
\text { called FAV (fluid } \\
\text { accumulation vest) }\end{array}$ & $\begin{array}{l}\text { BENEFICIAL } \\
\text { EFFECTS } \\
\text { Preventing HF } \\
\text { decompensations and } \\
\text { reducing } \\
\text { hospitalizations }\end{array}$ \\
\hline Kotb & 2015 & Metanalysis & 193 & $\begin{array}{l}\text { All-cause mortality, } \\
\text { hospitalization for } \\
\text { any cause or } \\
\text { hospitalization for HF }\end{array}$ & $\begin{array}{l}\text { Structured telephone } \\
\text { support or } \\
\text { non-invasive } \\
\text { home } \\
\text { telemonitoring }\end{array}$ & $\begin{array}{l}\text {-Telephone } \\
\text {-ECG \& video monitors } \\
\text { (applicable to some } \\
\text { studies) }\end{array}$ & $\begin{array}{l}\text { BENEFICIAL } \\
\text { EFFECTS } \\
\text { Lower rate of all-cause } \\
\text { mortality and hospi- } \\
\text { talizations for HF, im- } \\
\text { provement in patients' } \\
\text { quality of life }\end{array}$ \\
\hline $\begin{array}{l}\text { Ong-- } \\
\text { BEAT-HF }\end{array}$ & 2016 & $\begin{array}{l}\text { Interventional } \\
\text { study }\end{array}$ & 1437 & $\begin{array}{l}\text { Readmission from any } \\
\text { cause within }\end{array}$ & $\begin{array}{l}\text { Structured telephone } \\
\text { support and }\end{array}$ & $\begin{array}{l}\text {-Telephone } \\
\text {-ECG }\end{array}$ & $\begin{array}{l}\text { NO BENEFICIAL } \\
\text { EFFECTS }\end{array}$ \\
\hline
\end{tabular}


Table 1 (continued)

\begin{tabular}{|c|c|c|c|c|c|c|c|}
\hline Author & Year & $\begin{array}{l}\text { Type of the } \\
\text { study }\end{array}$ & $\begin{array}{l}\text { Number } \\
\text { of } \\
\text { patients }\end{array}$ & Endpoints & Method studied & Devices used in study & Results \\
\hline & & & & $\begin{array}{l}180 \text { days after } \\
\text { discharge }\end{array}$ & $\begin{array}{l}\text { non-invasive } \\
\text { home } \\
\text { telemonitoring }\end{array}$ & $\begin{array}{l}\text {-Weight scale } \\
\text {-Blood pressure } \\
\text { monitor }\end{array}$ & $\begin{array}{l}\text { No differences between } \\
\text { the interventional } \\
\text { group and the usual } \\
\text { care one }\end{array}$ \\
\hline Inglis & 2017 & Metanalysis & 9332 & $\begin{array}{l}\text { All-cause mortality or } \\
\text { hospital admissions } \\
\text { for HF }\end{array}$ & $\begin{array}{l}\text { Structured telephone } \\
\text { support or } \\
\text { non-invasive } \\
\text { home } \\
\text { telemonitoring }\end{array}$ & $\begin{array}{l}\text {-Telephone } \\
\text {-ECG } \\
\text {-Weight scale } \\
\text {-Blood pressure } \\
\quad \text { monitor }\end{array}$ & $\begin{array}{l}\text { BENEFICIAL } \\
\text { EFFECTS } \\
\text { Lower rate of all-cause } \\
\text { mortality and hospi- } \\
\text { talizations for HF, im- } \\
\text { provement in patients } \\
\text { quality of life }\end{array}$ \\
\hline Lin & 2017 & Metanalysis & 11,758 & $\begin{array}{l}\text { All-cause mortality, } \\
\text { length of intervention, } \\
\text { hospital admission } \\
\text { rate, and length of } \\
\text { hospital stay }\end{array}$ & $\begin{array}{l}\text { Structured } \\
\text { telephone } \\
\text { support or } \\
\text { non-invasive } \\
\text { home } \\
\text { telemonitoring }\end{array}$ & $\begin{array}{l}\text {-Telephone } \\
\text {-ECG } \\
\text {-Weight scale } \\
\text {-Blood pressure } \\
\quad \text { monitor } \\
\text {-Video consultation } \\
\text { equipment } \\
\text { (applicable to some } \\
\text { studies) }\end{array}$ & $\begin{array}{l}\text { BENEFICIAL } \\
\text { EFFECTS } \\
\text { Lower rate of all-cause } \\
\text { and HF-related } \\
\text { mortality, reduced ad- } \\
\text { mission rates, and } \\
\text { shortened HF-related } \\
\text { length of hospital stay }\end{array}$ \\
\hline$\frac{\text { Koehler- }}{\text { TIM-HF } 2}$ & 2018 & $\begin{array}{l}\text { Interventional } \\
\text { study }\end{array}$ & 1571 & $\begin{array}{l}\text { Days lost due to heart } \\
\text { failure hospitalization } \\
\text { or death }\end{array}$ & $\begin{array}{l}\text { Non-invasive home } \\
\text { telemonitoring }\end{array}$ & $\begin{array}{l}\text {-ECG } \\
\text {-Weight scale } \\
\text {-Blood pressure } \\
\text { monitor } \\
\text {-Pulse/oximeter }\end{array}$ & $\begin{array}{l}\text { BENEFICIAL } \\
\text { EFFECTS } \\
\text { Lower rate of all-cause } \\
\text { mortality and a re- } \\
\text { duced amount of days } \\
\text { lost due to unplanned } \\
\text { cardiovascular hospi- } \\
\text { tal admissions after a } \\
\text { follow-up of } 1 \text { year }\end{array}$ \\
\hline Nouryan & 2018 & $\begin{array}{l}\text { Interventional } \\
\text { study }\end{array}$ & 89 & $\begin{array}{l}\text { All-cause } \\
\text { hospitalization, length } \\
\text { of stay, and quality of } \\
\text { life }\end{array}$ & $\begin{array}{l}\text { Structured } \\
\text { telephone } \\
\text { support or } \\
\text { non-invasive } \\
\text { home } \\
\text { telemonitoring }\end{array}$ & $\begin{array}{l}\text {-Telephone } \\
\text {-Weight scale } \\
\text {-Blood pressure } \\
\quad \text { monitor } \\
\text {-Pulse/oximeter } \\
\text {-Video monitorware }\end{array}$ & $\begin{array}{l}\text { BENEFICIAL } \\
\text { EFFECTS } \\
\text { Lower rate of all-cause } \\
\text { hospitalization and } \\
\text { length of stay, im- } \\
\text { provement in patients' } \\
\text { quality of life }\end{array}$ \\
\hline Ware & 2018 & $\begin{array}{l}\text { Interventional } \\
\text { study }\end{array}$ & 98 & $\begin{array}{l}\text { Inform the design of } \\
\text { telemonitoring } \\
\text { services and } \\
\text { implementation } \\
\text { strategies of similar } \\
\text { telemonitoring } \\
\text { interventions }\end{array}$ & $\begin{array}{l}\text { Structured mobile } \\
\text { phone-based } \\
\text { support }\end{array}$ & $\begin{array}{l}\text {-Mobile phone } \\
\text {-Weight scale } \\
\text {-Blood pressure } \\
\text { monitor-Medly } \\
\text { mobile phone app }\end{array}$ & $\begin{array}{l}\text { BENEFICIAL } \\
\text { EFFECTS } \\
\text { Improvement in } \\
\text { patients' quality of } \\
\text { life }\end{array}$ \\
\hline Gingele & 2019 & $\begin{array}{l}\text { Interventional } \\
\text { study }\end{array}$ & 382 & $\begin{array}{l}\text { All-cause mortality rate, } \\
\text { number and length of } \\
\text { HF-related hospital } \\
\text { admissions, and num- } \\
\text { ber of outpatient clin- } \\
\text { ic visits due to HF } \\
\text { during } 1 \text { year of } \\
\text { follow-up }\end{array}$ & $\begin{array}{l}\text { Non-invasive home } \\
\text { telemonitoring }\end{array}$ & $\begin{array}{l}\text {-ECG } \\
\text {-Pulse/oximeter-Health } \\
\text { Buddy electronic } \\
\text { device }\end{array}$ & $\begin{array}{l}\text { NO BENEFICIAL } \\
\text { EFFECTS } \\
\text { Tailored telemonitoring } \\
\text { did not improve } \\
\text { health-related quality } \\
\text { of life in HF patients }\end{array}$ \\
\hline Zhu & 2019 & Meta-analysis & 10,981 & $\begin{array}{l}\text { All-cause } \\
\text { hospitalization, } \\
\text { cardiac } \\
\text { hospitalization, } \\
\text { all-cause mortality, } \\
\text { cardiac mortality, and } \\
\text { length of stay }\end{array}$ & $\begin{array}{l}\text { Structured } \\
\quad \text { telephone } \\
\text { support }\end{array}$ & $\begin{array}{l}\text {-Telephone } \\
\text {-ECG } \\
\text {-Weight scale } \\
\text {-Blood pressure } \\
\quad \text { monitor } \\
\text {-Pulse/oximeter }\end{array}$ & $\begin{array}{l}\text { BENEFICIAL } \\
\text { EFFECTS } \\
\text { Lower rate all-cause } \\
\text { hospitalization, cardi- } \\
\text { ac hospitalization, } \\
\text { all-cause mortality, } \\
\text { cardiac mortality, and } \\
\text { length of stay }\end{array}$ \\
\hline
\end{tabular}


The above table covers different studies from the past decade that aimed to assess if telemedical interventions and telemonitoring programs would be able to affect mortality, re-hospitalizations rate, or quality of life of HF patients. The type of study conducted, number of patients involved, endpoints, and devices are included for each study respectively. Finally, the effects of each study were evaluated as to whether they were beneficial or not

hospitalizations [31]. No ECG data nor other vital parameters were analyzed. Another study, the Interdisciplinary Network for Heart Failure (INH) trial, investigated the role of telephone-based monitoring and education, addressing individual problems of the patients, pursuing networking of healthcare providers, and providing training for caregivers [32]. Even though no reduction in re-hospitalizations was observed, mortality risk and reported patient surrogates of wellbeing improved significantly, suggesting that individualized care and consideration of non-cardiac problems understandable through telephone support should be integrated into the telemonitoring plans of HF patients [32]. The recent metanalysis by Zhu et al. showed instead that telephone support interventions are likely to reduce the hospitalization for all causes (OR 0.86, 95\% CI 0.78-0.96, $P=0.006$ ) and the hospitalization due to $\mathrm{HF}$ (odds ratio (OR) $0.74,95 \%$ CI $0.65-0.85$, $P<0.0001$ ), compared with interventions from conventional healthcare [30]. Moreover, it may also impact on cardiac mortality (OR 0.54, 95\%CI 0.34-0.86, $P=0.009$ ) [30].

\section{Body weight monitoring}

The main reason for the recurrent hospitalizations of $\mathrm{CHF}$ patients is a worsening of their disease state, characterized by an excessive decrease of the effective circulatory volume and a consequent mechanism of chronic body water retention [33]. When these patients are admitted to the hospital with body fluids congestion, high doses of diuretics are administered [33]. Further monitoring of the body water balance during the hospitalization is usually achieved via clinical observations regarding the patient's symptoms (e.g., dyspnea, peripheral edema, and pulmonary crackles), daily assessment of the body weight, and/or documentation of the patient's fluid input and output $[33,34]$. Usually, an improvement of the patient's symptoms can be achieved in a matter of days; however, in HF patients, ineffective treatment regarding body water retention can lead to clinical instability in terms of pulmonary edema up to death [34]. The paradigm assumed to identify deterioration of heart failure has been defined as an increase of body weight of $2 \mathrm{~kg} / 48 \mathrm{~h}$ [34]. Even if this threshold derives more from a consensus agreement rather than from clear clinical evidence, it is still one of the most utilized parameters of remote home monitoring of HF patients [34]. In their clinical trial, Chaudry et al. used weight scales as their primary device to assess data. Using this evaluation of patients' health status, the study was not able to confirm any beneficial effects from telemonitoring [31]. This study did not include any ECG analysis nor other vital signs, supporting the fact that monitoring patients' body weight alone may be less beneficial than utilizing a combination of different parameters [31]. Another study that was not able to prove any significant decrease in re-hospitalizations nor mortality in the intervention group was the BEAT-HF [35]. Signals of daily changes in weight did not prove adequate warning of impending decompensation [35]. The presence of multiple parameters and multiple devices, instead, seems be more beneficial in detecting better decompensation events. An example of a study in which body weight monitoring combined with additional parameters from multiple devices was conducted in 2018 by Nouryan et al. [36]. Devices used in this study included a weight scale, a blood pressure monitor, pulse/ oximeter, and a video monitor [36]. This study confirmed beneficial effects from telemonitoring including lower rate of all-cause hospitalizations and length of stay, as well as improvement in patients' overall quality of life [36].

\section{ECG monitoring}

Among the different non-invasive technologies, ECG monitoring remains a relatively under-investigated topic for the remote monitoring of $\mathrm{HF}$ patients [29]. Electrocardiographic technology has become more and more prevalent since its development in the 1950s [20]. ECG examinations have moved from in-hospital to ambulatory settings and nowadays have the possibility of becoming more mobile and accessible [20]. With the emergence of the Internet, Wi-Fi, cellular networks, and broad-band transmission, it is easier to perform such examinations remotely today [20]. Even if recently the potential for ECG examinations being used digitally in combination with smartphone applications and miniaturized devices or wearables is staggering [20, 37, 38], there is more than ever the need of further clinical randomized trials for such new devices [39]. In a study by Cleland et al., ECG data transmission was significantly associated with reducing hospitalizations due to HF when compared with usual care [40]. In a study by Villani et al. which analyzed HF patients at high risk of relapse, the regular acquisition of simple clinical information as well as the possibility for the patients to contact the clinical staff and having access to the ECG data, produced better psychological status, quality of life, and reduced hospitalizations for HF patients [41]. A metanalysis by Kotb in 2015 focused primarily on assessing ECG tracings, telephone support, and video monitors to abstract data for the study [29]. The prominent role of the ECG in this analysis proved beneficial as the study showed substantial beneficial positive effects including lower rates of all-cause mortality and 
hospitalizations, and an improvement in quality of life for HF patients [29]. The extent to which ECG is useful and to which type of HF patients should be applied is, however, still to be completely determined. For instance, in a study conducted by Ferrante et al., the intervention group did not use the ECG as a parameter, yet the effects of the study were still shown to be beneficial in terms of lower rates of all-cause mortality and hospitalization in HF patients [22]. Similar to the study by Ferrante et al., the study conducted by Nouryan et al. in 2018 had success by using different telemonitoring methods apart from ECG data [36]. Despite not having ECG measurements, this version of telemonitoring showed beneficial effects including lower rates of all-cause hospitalization, length of stay, and improvement in patients' quality of life [36]. Much literature has been published on the utility of the ECG for predicting HF worsening in chronic HF patients. The parameters which were found to predict the risk of a heart failure decompensation event are summarized in Table 2.

\section{Bioimpedance monitoring}

Body weight assessment is an imprecise estimation of the body fluid composition since it can be influenced by a wide variety of factors [52]. Bioimpedance analysis is a way to measure the body composition, by assessing the lean and fat body mass, total body water, and extracellular/intracellular water [52]. While a single measurement of the patient's fluid status is not particularly useful, a relative change of the patient's fluid balance is crucial in HF patients [52]. For this reason, a sensible way of analyzing the patients' body water overload was firstly obtained invasively through a current generated from the pacing wires of pacemakers and defibrillators [53, 54]. This kind of measurement estimates the fluid overload locally inside the thorax of the patient. As an example, Medtronic developed a CRT-ICD device which is equipped with an internal impedance-meter called Opti-Vol. This feature for bioimpedance analysis has been evaluated in the DOT-HF trial with the objective to test whether Opti-Vol would affect the clinical outcomes of CHF patients [55]. Interestingly, the intervention arm has been shown to be associated with a borderline statistically significant increase in the primary endpoint composed by all-cause mortality and HF hospitalizations compared with the standard care one. This increase was mostly due to increased HF-related admissions. This can be explained by the fact that an increase in the incoming additional diagnostic data obtained from the Opti-Vol method provided an increase in HF hospitalizations [55]. To implement a possible way of monitoring the fluid status of HF patients with external devices instead, some studies were conducted to assess the possible utilization of non-invasive bioimpedance analysis for the remote management of HF patients [52]. One interventional study, called MUSIC (Multisensor Monitoring in Congestive Heart Failure), was initiated to develop and validate an algorithm for prediction of impending acute heart failure decompensation with the use of different physiological parameters, including bioimpedance analysis, obtained from an external device adhered to the chest [56]. Five hundred forty-three HF patients with an ejection fraction less than $40 \%$ and a recent $\mathrm{HF}$ admission were recruited. They were remotely monitored with a multi-sensor device for 90 days [56]. A total of 314 patients were included in the analysis: 114 in the development cohort, and 200 in the validation cohort [56]. A multi-parameter HF detection algorithm was developed from the obtained data in the
Table 2 Overview and definition of the most studied ECG parameters predicting decompensation events in cardiological patients

\begin{tabular}{|c|c|}
\hline Parameters & Definition \\
\hline Reduced heart rate variability [18] & $\begin{array}{l}\text { Reduction in time domain differences between day and night observed at } \\
\text { Holter monitoring }\end{array}$ \\
\hline Increased heart rate [42] & Tachycardia and increase in the basal heart rate \\
\hline QRS/T angle increase [43] & $\begin{array}{l}\text { Increase in the repolarization axis angle }\left(>60^{\circ} \text { for women and }>120^{\circ} \text { for }\right. \\
\text { men) }\end{array}$ \\
\hline $\begin{array}{l}\text { Atrial and ventricular } \\
\text { tachyarrhythmias }[19,44]\end{array}$ & $\begin{array}{l}\text { Atrial flutter and fibrillation and ventricular non-sustained and sustained } \\
\text { ventricular tachycardia }\end{array}$ \\
\hline Increased ECG LV mass $[20,45]$ & More than $70 \pm 9 \mathrm{~g} / \mathrm{m}^{2}$ in men and $61 \pm 8 \mathrm{~g} / \mathrm{m}^{2}$ in women \\
\hline QT prolongation $[46]$ & $\mathrm{QTc}>450 \mathrm{~ms}$ (males) QTc $>460 \mathrm{~ms}$ (females) \\
\hline Increased QRS duration $[47,48]$ & $\begin{array}{l}\text { QRS }>100 \text { ms with or without complete and/or incomplete bundle } \\
\text { branch blocks (left or right) }\end{array}$ \\
\hline LV strain $[17,49,50]$ & ST segment depression and T wave inversions \\
\hline $\begin{array}{l}\text { An old silent myocardial infarction } \\
\text { [51] }\end{array}$ & Novacode Criteria published in the article by Rautaharju et al. [51] \\
\hline
\end{tabular}

ECG data and parameters allow physicians to have a better psychological status of the patient for better predictions. The preceding table displays the parameters which were found to predict the risk of a heart failure decompensation. Each individual risk is accompanied by a definition for reference 
development cohort. This algorithm had a $65 \%$ sensitivity and 90\% specificity for the detection of HF events in that cohort and met the pre-specified endpoints in the validation cohort with a sensitivity of $63 \%$ and specificity of $92 \%$ [56]. However, whether this method would affect the clinical outcome of CHF patients was not studied and is still yet to be determined [56]. A recent study, called SENTINEL-HF, examined a transthoracic bioimpedance vest called FAV (Fluid Accumulation Vest) in 180 patients hospitalized for HF [57]. The patients were trained to autonomously perform daily bioimpedance measurements and transmit them via their smartphone to the clinic of reference [57]. This preliminary study identified that the use of FAV allowed to predict the occurrence of hospitalizations up to 7 days in advance in the intervention group [57]. However, further studies are needed to assess the role of bioimpedance analysis in preventing hospital admissions.

\section{Applications, software, and new technologies}

Digital health is an increasingly emerging medical field [58]. Advances in technology were translated into healthcare due to access of an immense amount of data, to new software platforms, and even to the use of Artificial Intelligence (AI) [59]. The development of digital health has been recognized by the European Society of Cardiology with the recent establishment of the Digital Health Virtual Journal in August of 2019 [58, 59]. This journal was established to give information about the digital revolution in cardiology. This momentum of use of digital health in clinical practices and research is expected to rise in the years to come $[58,59]$. Already many examples of digital health have been seen in several studies through their use of technology in relation to HF patients as well as devices used in telemonitoring methods $[58,59]$. An example is given by the pilot study investigating a device called MedSentry, a remotely monitored electronic pillbox, that alerts patients when it is time to take their medication and connects patients with caregivers in case the medication was not taken, showed a reduction in all-cause hospitalizations and all-cause length of stay in the intervention group [60]. Ware et al. conducted another study which took a different approach to telemonitoring by using the Medly mobile phone application that allows patients to record their blood pressure, body weight, and symptoms on a daily basis [61]. Patients received an automated phone call if they had not taken their readings before $10 \mathrm{AM}$ to encourage participation [61]. Assessing the user inputs, Medly's algorithms can output self-care messages as well as clinician alerts based on patient-driven target ranges [61]. The study's aim was to integrate Medly as part of the standard of care of HF patients. Gingele et al., instead, made use of an electronic device called Health Buddy [62]. This device, made up of a display screen and four buttons, presents the patient with health education and self-care support and additionally relays questions about the patient's symptoms that are then collected by a protected server [62]. These studies are an example of how applications, software, and other devices represent the new frontiers of telemedicine to come.

More and more devices, often referred to as wearables and being a part of mobile health (mHealth), are taking place in our daily life. These biosensing products come in a variety of different forms and are often integrated into clothing or accessories (e.g., watches). Wearables offer the possibility of continuously collecting functional or physiological data outside the hospital [39]. Previous evaluations of wearables in patients with heart failure mainly focused on pedometers and activity trackers showing for example that wireless mobility monitoring after cardiac surgery was feasible and practical [63], or that cardiac tele-rehabilitation via a call center can support walking activity using pedometers leading to an incorporation of step count into the intervention [64]. In consequence, wearables not only have the capacity of assessing data but also become components of clinical trials in the form of interventions and endpoints [39]. Furthermore, Chan et al. screened heart failure patients for atrial fibrillation by using handheld ECG recording devices (AliveCor device, San Francisco, CA) that transmits to a smartphone application, showing the feasibility and identification of a significant proportion of patients with newly diagnosed atrial fibrillation [65]. Further technologies as for example vests measuring thoracic fluid content [66] and ballistocardiogram or seismocardiogram devices measuring whole-body movements and chest wall vibrations are emerging in order to detect cardiac decompensation events [67]. Overall, wearables have the possibility to improve care and outcomes in heart failure patients; however, the current data is limited to feasibility studies and small randomized controlled trials [39].

\section{Lung ultrasound}

Lung ultrasound (LUS) became a valuable diagnostic tool in patients with heart failure over the last decade. As a point of care test, it emerged as a simple and non-invasive tool for the detection of pulmonary congestion and cardiac filling pressures $[68,69]$. Studies have shown a fast learning curve and high inter-observer agreement [70, 71]. European guidelines support its use in patients with acute heart failure [1, 72]. Furthermore, LUS is even more effective to detect pulmonary congestion than clinical examination, chest X-ray or NTproBNP measurements [73, 74]. The technique is based on the detection of B-Lines which is defined as a kind of comettail artifact indicating subpleural interstitial edema. The number of B-lines correlates with the presence of extravascular lung water and identifies patients with worse outcome very well $[69,70]$. This has been shown in both in- and outpatient heart failure cohorts with persistent B-lines at discharge [75-77]. As a first randomized control trial, the LUS-HF study 
evaluated the use of lung ultrasound to guide the ambulatory follow-up over a period of 6 months in 123 patients which were hospitalized due to heart failure [78]. Patients were randomized either to the LUS-guided group or the standard care group. In both groups, lung ultrasound was performed with a pocket ultrasound device (VScan; GE Healthcare, Chicago, IL, USA) [78]. Only patients were blinded to their group assignment. The treating physicians were not blinded; however, the LUS results were withheld in the standard care group. Diuretic therapy was modified if number of B-lines recorded by LUS surpassed more than 3 B-Lines in 8 chest zones. The study could show that patients in the LUS group had a significantly improved combined primary endpoint of urgent visits, hospitalization for worsening heart failure, and all-cause death over a 6-month follow-up [78]. In addition, there was no difference regarding the risk of adverse events between both groups. As a non-invasive, easy to handle, and cost-effective method, LUS might be a broadly applicable approach to monitor cardiac decompensation in heart failure patients. Of course, further and larger trials are needed to prove that LUS-guided therapy management of heart failure patients in different settings is truly beneficial and to better define B-line cutoff values, establish treatment strategies, and identify subgroups that are more likely to benefit $[79,80]$. A systematic review by Swamy et al. could show that HF nurses as well as other healthcare providers can quickly optimize the performance of LUS and interpret B-Lines and pleural effusions as signs of pulmonary congestion in patients with heart failure [79]. HF nurses are well-established and important players in the management and care of HF patients. The incorporation and performance of LUS by trained nurses may further improve care and reduce costs in this cohort of patients. Several studies support the possibility that nurse-performed ultrasound examinations is highly valuable to stratify ambulatory HF patients according to risk as well as improve their management likewise applicable in regions of limited resources [76, 81-83].

\section{Natriuretic peptides}

Natriuretic peptides, as the B-type natriuretic peptide (BNP) and amino-terminal pro-B-type natriuretic peptide (NTproBNP), are biomarkers which are used for the diagnosis of heart failure. They reflect severity of heart failure and are also significantly associated with adverse outcomes as well as prognosis of patients with heart failure [84, 85]. If serial BNP measurements are useful to guide heart failure therapies is still uncertain. Several clinical trials of different size and design regarding this question have shown mixed [84-87]. In a promising meta-analysis by Troughton et al. natriuretic peptide-guided therapy of patients with heart failure, a reduction of all-cause mortality in patients aged $<75$ years and overall reduction of heart failure and cardiovascular hospitalization were shown [88]. However, the succeeding GUIDE-IT trial found that NT-proBNP-guided therapy was not more effective than standard care in improving outcomes in patients with HFrEF [89]. The trial was stopped for futility due to no significant differences between the NT-proBNP guided group and the usual care group regarding primary and secondary endpoints. The primary end point consisted of a composite of time-to-first heart failure hospitalization or cardiovascular mortality. The PRIMAII trial (Can NTProBNP-Guided Therapy During Hospital Admission for Acute Decompensated Heart Failure Reduce Mortality and Readmissions?) demonstrated similar results showing that a NT-proBNP guided heart failure therapy with a reduction of NT-proBNP $<30 \%$ did not improve 6-month outcomes in conditions of acute heart failure [90]. The Heart Failure Outpatient Monitoring Evaluation (HOME) study on heart failure patients with reduced ejection fraction and recent heart failure hospitalization suggested that daily home BNP measurements could predict impending clinical deterioration [91]. Earlier trials used infrequent monitoring of natriuretic peptides, potentially underestimating its actual benefit. The HOME study was designed as a randomized clinical trial to discourse whether daily BNP measurement integrated into a home monitoring system improved outcome compared to a home monitoring system without daily BNP measurements and a third arm consisting of a usual care approach [91]. The study was terminated prematurely because of a low enrolment rate, low event rate regarding the primary endpoint, and the lack of a formal algorithm to interpret and act upon changes in BNP trends [91]. As a consequence, the data from all study arms was pooled and an analysis as a single observational study was performed. The HOME study could confirm that BNP home measurements are safe and feasible which is consistent to the previous published HABIT (Heart Failure Assessment With BNP in the Home) trial [91, 92]. Regarding the used remote home monitoring device, BNP measurements were realized by the Alere ${ }^{\mathrm{TM}}$ Heart Check system with a finger-stick self-testing sample at home. At the time of weight measurement, subjects were instructed to perform their daily BNP analysis each morning before breakfast and morning medication. The weight of the patients was assessed by digital scales that transferred information wirelessly to the HeartCheck system. Furthermore, subjects had to answer five questions concerning typical heart failure symptoms for daily clinical status evaluation BNP measurements showed a high day-today variability which increased with a prolongation of measurement intervals [42, 93]. McDonald et al. calculated a moving average filter (fBNP) to reduce day-to-day variations and assess weekly changes, showing that fBNP was able to predict an emerging acute cardiac decompensation [93]. Interestingly, secondary results of the HOME trial showed differences between patients with $\mathrm{HFpEF}$ or HFrEF regarding their BNP and weight values 
before decompensation [43]. Randomized clinical trials are needed to determine if changes in daily BNP measurement have an impact on outcome. We summarized the advantages and disadvantages of the emerging and further new applications in Table 3.

\section{Discussion}

\section{Is non-invasive telemonitoring beneficial or not?}

Despite all the new advances in therapy, the management of CHF patients remains a massive burden for the healthcare system [44]. This is only worsened by the increasing lack of medical doctors with expertise in HF management, becoming a relevant issue particularly in rural areas of Countries such as Germany or the UK [44]. Therefore, telemedical care has been recently proposed as a potentially efficient and cost-effective way to provide care and improve the outcome of HF patients [44]. Many studies have been conducted, providing both invasive and non-invasive solutions for HF patients [44]. In recent years, a broad consensus concerning the favorable prognostic impact of implantable hemodynamic monitoring has been reached. Invasive telemonitoring, such as via pulmonary artery monitoring (cardioMEMS ${ }^{\mathrm{TM}}$ ) [45] or via ICD multi-parameter monitoring (the IN-TIME approach) [25], has therefore already been integrated in the 2016 ESC HF guidelines with a class IIb level of recommendation [1]. A certain disagreement, instead, is still present about the effectiveness of non-invasive methods in reducing patients' hospitalizations, and this type of monitoring is not part of any guidelines or consensus agreement yet [46, 47].

In the last 10 years, different randomized clinical trials were performed to finally reply to this question and to prove the utility of non-invasive RPM [23, 24, 35]. From 2008 until 2011, a large randomized multicenter trial, the Telemedical Interventional Monitoring in Heart Failure (TIM-HF), was designed to investigate whether RPM would reduce mortality and hospitalizations in ambulatory chronic HF patients compared to usual care [23]. External devices for ECG, blood pressure, and body weight measurements were connected via Bluetooth to the patient's home, and information were sent to the Center Monitors continuously 24/7 [23]. The primary endpoint was death from any cause. The secondary endpoint was a composite of cardiovascular death and hospitalization for HF [23]. The results of TIM-HF suggest that when RPM is applied to stable, optimally treated, ambulatory chronic HF patients, a reduction in mortality and re-hospitalizations is not evident. However, this study confirmed that noninvasive telemonitoring improves the quality of life of HF patients [23]. Another large trial, the BEAT-HF that enrolled 1437 participants investigated the role of combined health coaching telephone calls and telemonitoring [35]. The primary outcome, namely readmission for any cause within 180 days after discharge, was not different between the intervention group compared to the standard care group [35]. In a secondary analysis, there were no differences in 30-day readmission or 180-day mortality, but there was a significant difference in the 180-day quality of life between the intervention and usual care groups [35].

Published in 2018, the Telemedical Interventional Management in Heart Failure II study (TIM-HF II), the more extensive follow-on study to the TIM-HF trial, by Koehler et al., was the first non-invasive randomized-controlled trial which showed an improvement in all-cause mortality by RPM in patients with heart failure [24]. The study was conducted from 2013 till 2017 and 1571 patients with heart failure were included and randomly assigned either to the remote patient monitoring group $(n=796)$ or to the standard care group $(n=$ 775) [24]. The non-invasive telemonitoring system, which was installed in the patient's home, consisted of a threechannel ECG, a blood pressure monitoring device, a pulse oximeter, and a weight scale [24]. Patients were equipped with a mobile phone to contact the telemedical center in case of emergencies [24]. Likewise, a monthly follow-up was achieved via structured phone interviews with the patients [24]. The telemedical center provided patients with $24 \mathrm{~h}$ a day and 7 days a week of medical support led by physicians and heart failure nurses, being able to act immediately according to the patient's specific risk profile [24]. The interventions initiated by the telemedical center involved changes in medication, initiation of ambulatory assessments, hospital admission, and educational activities [24]. The primary endpoint of days lost due to unplanned cardiovascular hospital admissions and all-cause mortality (in \%) showed a significant advantage after a follow-up of 1 year for patients in the RPM group compared to the control group (hazard ratio $0.80 ; 95 \% \mathrm{CI}$ $0.65-1.00 ; P=0.046$ ) [24]. Per year, patients in the RPM group lost a mean of 17.8 days (95\% CI 16.6-19.1) compared with 24.2 days (95\% CI 22.6-26) per year for patients assigned to the control group [24]. In addition, the all-cause death rate per 100 person-years of follow-up was significantly reduced in the RPM group [7.86 (95\% CI: 6.14-10.10)] compared to the control group [11.34 (95\% CI: 9.21-13.95)] per 100 person-years of follow-up (hazard ratio $0.70 ; 95 \% \mathrm{CI}$ $0.50-0.96 ; P=0.0280$ ) [24]. There was no significant difference in cardiovascular mortality between the two groups (hazard ratio $0.671,95 \%$ CI $0.45-1.01 ; P=0.056$ ) [24]. These results show that non-invasive telemonitoring can lead to an improvement in prognosis and a reduction of hospital admissions in high-risk patients [24].

Besides clinical trials, metanalyses on telemonitoring and telephone support have been performed, suggesting that RPM could provide better clinical outcomes than usual care, with a reduction in mortality and hospital admissions observed [48-50]. In the Cochrane Review by Inglis et al. in 2010, 25 


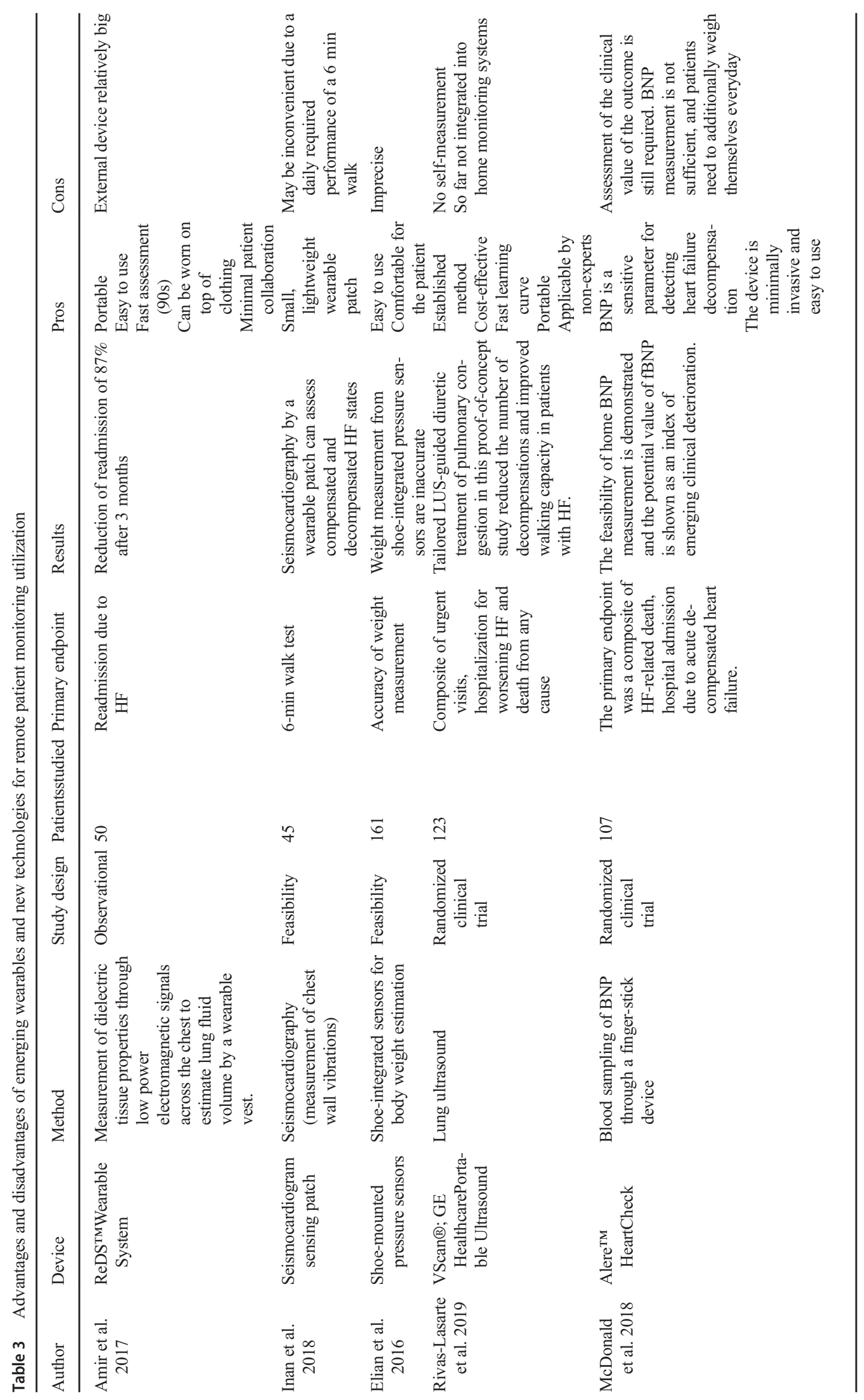


full peer-reviewed studies on non-invasive telemonitoring were included in the analysis and incorporated 8323 patients [48]. In addition to examining the impact on heart failurerelated hospitalization and mortality, the review also considered the quality of life (QOL), acceptability of the systems, and cost efficacy [48]. Telemonitoring reduced all-cause mortality (relative risk (RR) $0.66,95 \%$ confidence interval (CI) $0.54-0.81, P<0.001$ ), whereas telephone support demonstrated a non-significant reduction (RR 0.88, 95\% CI 0.76-1.01, $P=0.08$ ) [48]. Both telemonitoring and telephone support produced significant reductions in heart failure-related hospitalizations (RR $0.79,95 \%$ CI $0.67-0.94, P=0.008$ and RR $0.77,95 \%$ CI $0.68-0.87, P<0.001$, respectively) [48]. In a further investigation of the beneficial qualities of telemonitoring, Inglis et al. performed a more recent study in 2017 which included the latest clinical trials and showed that the telemonitoring interventions improved quality of life, reduced the costs, and were acceptable for the patients [50]. Telemonitoring showed a reduction of $20 \%$ of all-cause mortality compared to standard of care [50]. For Inglis et al., improvements in drug prescriptions, patient-knowledge, and self-care and functional classes were observed [50]. In a further metanalysis conducted by Lin et al. in 2017, devices studied included ECG, weight scale, blood pressure monitor, and video consultation equipment [51]. The number of participants consisted of a total of 11,758 patients, of which 5935 subjects belonged to the telemedicine groups, while 5823 subjects were in the control group [51]. The outcomes of the study supported telemonitoring being beneficial to patient's health, specifically resulting in a lower rate of all-cause and HFrelated mortality, reduced admission rates, and shortened HF-related length of hospital stay for the telemedical group [51]. The most recent metanalysis published by Zhu et al. and incorporating 10,981 patients displayed the beneficial effects of telemonitoring such as lower rates of all-cause hospitalization, cardiac hospitalization, all-cause mortality, cardiac mortality, and length of hospital stay, adding an important contribution to the discussion [30].

Telemonitoring as an intervention has been shown to reduce symptoms and improve quality of care through frequent monitoring of patients at home $[24,28]$. This, however, needs to be coherent with an easy utilization of these devices that need to be portable and usable for everyone. Of extreme relevance is the consideration that most of the population with CHF are patients older than 65 years [94]. The metanalysis by Inglis tackled this subject and revealed that no differences in age ranges affected the outcome and the adherence to telemonitoring in the studies analyzed [94]. Ware et al. conducted an additional study measuring patient adherence to a mobile phone-based HF telemonitoring program in 2019 [95]. The results of this study showed the highest and most consistent adherence among elderly patients, while the adherence of younger patients decreased over time [95]. These studies confirm that elderly patients are able to adapt to technology for healthcare purposes [94, 95].

The more frequent assessment of the patient status and an earlier recognition of decompensation events through RPM represents a recognized benefit [96]. Telemonitoring provides the patients with a structured disease management process and can be self-empowering, meaning that the patient is actively involved in controlling his health status and lifestyle [96]. This is consequent and in line with the role of the patient that has entirely changed in recent years, switching from a passive to an active role given by the spread of medical knowledge through the internet and a growing attention to personal health [96]. Eventually, a further positive aspect of telemedical solutions is represented by the incorporation of human interaction, such as between the patient and the physician, or the nurse, for example via telephone, where this contact can also detect depression, which is a known risk factor of poor outcome in $\mathrm{HF}$ patients [96].

\section{Economic aspect and reimbursements}

Whether telemonitoring is a tool to decrease the costs of care for HF patients mainly by reducing hospitalizations and lengths of hospital stay has been a matter of discussion in different papers [97-101]. In a randomized controlled study by Dendale et al., the total hospitalization cost for heart failure and/or renal failure in a group of HF patients was almost double in the usual care group $(1458+3420 € /$ patient $)$ as compared with the telemonitoring group $(902+2277 € /$ patient), even if this difference was not found significant $(P=$ 0.23 ) [97]. In a systematic review performed by Seto, a cost comparison analysis was performed between telemonitoring and usual care in HF patients [99]. The studies included in the review showed costs reduction ranging from 1.6 to $68.3 \%$, mainly attributed to a reduction in heart failure hospitalizations [99]. Cost reductions were mainly attributed to reduced hospitalization expenditures. Only one study discussed the impact of HF telemonitoring on direct patient costs. The study found a $3.5 \%$ lower travel cost for patients using telemonitoring compared to those in the usual care group. The single study that was found for indirect costs described the willingness to pay for telemedicine by patients with HF (55\% of the patients with HF were willing to pay $\$ 20$ to access telemedicine, and $19 \%$ were willing to pay \$40) [99].

The group of Blum et al. has instead obtained contrasting data, and they mostly concentrated in understanding the effects of home monitoring on medical costs, 30-day re-hospitalization, mortality, and health-related quality of life [100]. Telemonitoring did not result in lower total costs and a decrease in 30-day readmission rates for the first year and did not result in decreased total costs or better outcomes [100]. A metanalysis by Klersy et al. demonstrated that RPM compared to usual care generates a cost-saving combined with a quality- 
adjusted life years (QALYs) gain of 0.06 suggesting that RPM is a "dominant" technology over existing standard care [101]. In the budget impact analysis, the adoption of an RPM strategy entailed a progressive and linear increase in costs saved [101]. The difference in costs between RPM and usual care ranged from $300 €$ to $1000 €$ per patient per year based on the Diagnosis Related Group (DRG), favoring RPM [101]. The higher the DRG, the greater the saving [101].

\section{What is the evidence on target patient population and optimal measure frequency?}

The optimal timing of telemonitoring is not yet established. A meta-analysis by Nakamura et al. suggests that a high measurement frequency ( $>$ twice a week) is more effective in reducing mortality than a lower measurement frequency $(\leq$ once a week) [102]. A relevant argument in favor of a daily monitoring if vital signs is related to the potential risk of sudden heart failure of these patients [102]. Moreover, the strongest benefit can be achieved if daily telemonitoring is linked to a specific action, such as medication adjustment or increased medication adherence. Of importance, a medical doctor or a specialized nurse should always be present to review the parameters telemetrically in order to prescribe and adjust any type of medication. Even in the presence of advancements in artificial intelligence and automated software, the role of a specialized figure is still unavoidable. In particular, specialized HF nurses are known to play a crucial role for the management of HF patients, specifically in cases of cardiac rehabilitation programs or home-based telemonitoring [103]. The turning point is driven by the fundamental influence that the specialized nurses can provide in improving quality and delivery of care to the HF patient [104], going beyond the supervision of vital parameters by positively affecting the patients' self-care and psychological status [105].

Which type of patients should benefit more from noninvasive telemonitoring and at which timing this should be applied, represent still open themes for discussion. The White Paper from the Heart Failure Society of America Scientific Statements Committee states that external devices should be focused on populations at higher risk [47]. However, the exact criteria for selection of patients at risk and in need of telemonitoring are still far from being widely approved. The most relevant criteria refer to symptomatic patients (NYHA class 3), with recent hospitalizations, a history of body fluids overload and a lack of appropriate medication adherence $[106,107]$. Patients with very advanced disease or with significant renal insufficiency may be too ill to achieve benefit from RPM. For this reason, it is reasonable to think that telemonitoring should be provided as a solution for patients at high risk and mostly right at the hospital discharge, since there is evidence that the first 30 days are characterized by high morbidity and mortality for HF patients. This should be however personalized by considering patients characteristics and related comorbidities, while justifying the extension of a telemonitoring plan up to 6 months in individual cases (such as patients prone to fluid overload or lacking a rigorous medication adherence).

\section{What needs to be changed or improved?}

An answer that still needs to be fully replied is to which type of HF patients shall be telemonitoring applied and which type of non-invasive devices shall be utilized. First of all, the accuracy and the clinical value of the specific medical devices should be considered. An example can be given by the utilization of standard weight scales [98]. Even if the remote monitoring of the patient's body weight is currently considered not sensitive enough to detect early cardiac decompensation events, it is still one of the most used methods for controlling the patient's status remotely, mainly because of the affordability and of the vast spread of standard weight scales [98]. It should be, instead, substituted by more accurate techniques for the measurement of the patients' volume status [98]. One possible solution for a new sensory technique may be through the use of bioimpedance analysis. While weight scales are not sensitive enough to detect early cardiac decompensation events, bioimpedance analysis is able to provide a noninvasive approach in predicting volume overload before a given volume overload affects body weight [98]. Although being more accurate than weight scales, there are still limitations to bioimpedance analysis. One of them is related to the water distribution in the body that changes with the patient's degree of obesity and on populations-specific bioimpedance equations $[98,108]$. Morbidly obese patients experience a relatively high amount of extracellular water and total body water. This inconstant hydration factor can lead to underestimation of the percentage of body fat and an overestimation of fat-free mass [98].

Currently, the profile of patients who can potentially benefit from telemedicine should be further investigated in adequately powered randomized clinical trials [46]. In HF patients, the presence of comorbidities, such as chronic obstructive pulmonary disease, chronic kidney disease, or anemia, for example, can negatively affect their outcome [98]. The assessment and the measurement of these comorbidities will need new sensory techniques and new specific devices that have to be addressed to the specific patients' characteristics [98]. Since nowadays the spread of portable and affordable external devices is increasing, many of which connected to smartphones, more clinical trials on the usefulness of these devices would be helpful to assess their actual clinical utility [46]. Much literature has been published about the role of ECG for predicting cardiac decompensations in chronic HF patients (Table 2). However, these parameters are rarely utilized to predict the patients' decompensation events remotely 


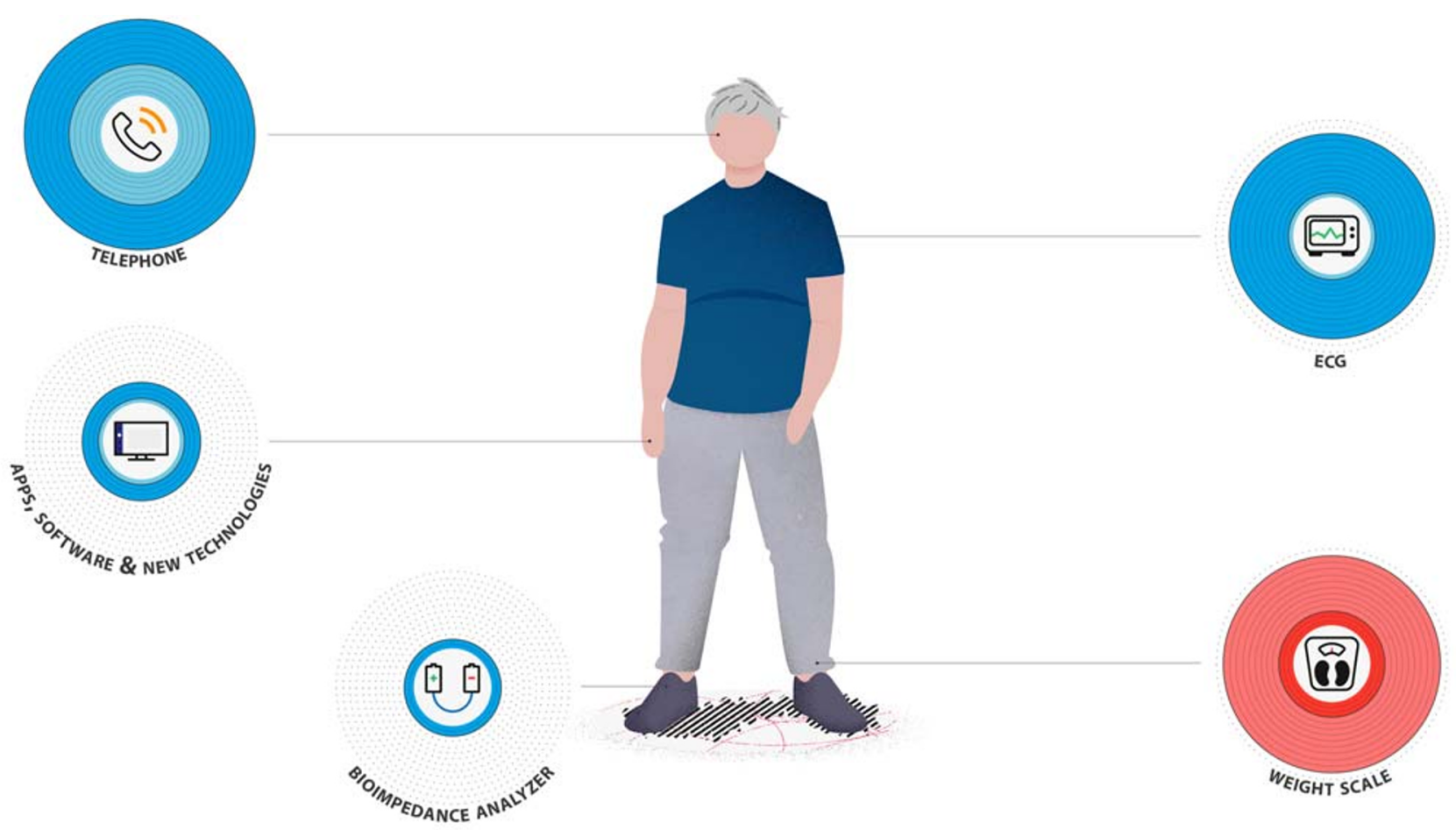

Legend

Effective Devices

Beneficial studies
Non-beneficial studies
Ineffective Devices

Beneficial studies
Non-beneficial studies
Fig. 1 Overview of non-invasive devices commonly used for the remote monitoring of heart failure patients. The devices are sized according to how much have been investigated in the literature, with the larger circles

[46]. For this reason, either new devices or new algorithms are needed to improve the diagnosis and the risk stratification workflow of HF patients remotely [46].

In conclusion, several study techniques and their applicable devices have been discussed and evaluated for their usefulness in monitoring remotely HF patients and have been summarized in Fig. 1. Telephone support is a useful technique that allows patients to have contact with a healthcare professional and allow frequent updates, yet this kind of measurement alone is not specific enough to make predictions about the patients' health. Weight scales used to monitor body weight changes are not found to be useful as the patient's weight is currently considered not sensitive enough to detect early cardiac decompensations. ECG monitoring is an extremely useful technique that provides important patient data yet remains still under-investigated, mainly regarding which population of HF patients would benefit the most. Bioimpedance analysis is a promising form of telemonitoring with great potential; however, there is a lack of evidence for such a technology for remote patient monitoring. Moreover, until now, bioimpedance analysis has been contraindicated in patients corresponding to the most studied devices. The devices are also categorized by their effectiveness in evaluating a patient's health status: effective (blue) or ineffective (red)

implanted with pacemakers, even if numerous studies were able to demonstrate a high level of safety and no adverse events in this population of patients [109-111].

Summing up, the use of only one parameter or device is definitively insufficient [112], while the combination of several parameters and different targeted devices represents the ideal approach, as in the TIM-HF II trial [24].

\section{Conclusions}

Modern advances in technologies have created new opportunities to provide telemedical care as an adjunct to medical management of patients with HF. Non-invasive telemonitoring can reduce morbidity and mortality in these patients as demonstrated by different meta-analyses and the recent clinical trial TIM-HF 2. The debate on the utility of non-invasive devices for home telemonitoring should concentrate on obtaining parameters and prediction algorithms based on more personalized risk profiles of HF patients. 
Acknowledgments Open Access funding provided by Projekt DEAL. We would like to thank Simone Proietti Timperi for performing the graphical illustration.

Author contribution A.F., A.A., and D.A. ideated the article; A.F., C.Q., and D.A. performed the literature search and data analysis; A.F., A.A., M.C., T.S., H-D. D., B.P., S.K., and F.E. drafted and/or critically revised the work.

\section{Compliance with ethical standards}

Conflict of interest Alessandro Faragli is a shareholder of the Company BOCAhealthcare GmbH. Burkert Pieske reports having received consultancy and lecture honoraria from Bayer, Daiichi Sankyo, MSD, Novartis, Sanofi-Aventis, Stealth Peptides, and Vifor Pharma; and editor honoraria from the Journal of the American College of Cardiology. Burkert Pieske, Frank Edelmann, and Sebastian Kelle received funding from the DZHK (German Centre for Cardiovascular Research) and by the BMBF (German Ministry of Education and Research). Sebastian Kelle received an unrestricted research grant from Philips Healthcare and received lecture honoraria from Medis, NL. Dawud Abawi, Caroline Quinn, Mina Cvetokovic, Thomas Schlabs, Elvis Tahirovic, and Hans-Dirk Düngen have no conflicts of interest or financial ties to disclose.

Open Access This article is licensed under a Creative Commons Attribution 4.0 International License, which permits use, sharing, adaptation, distribution and reproduction in any medium or format, as long as you give appropriate credit to the original author(s) and the source, provide a link to the Creative Commons licence, and indicate if changes were made. The images or other third party material in this article are included in the article's Creative Commons licence, unless indicated otherwise in a credit line to the material. If material is not included in the article's Creative Commons licence and your intended use is not permitted by statutory regulation or exceeds the permitted use, you will need to obtain permission directly from the copyright holder. To view a copy of this licence, visit http://creativecommons.org/licenses/by/4.0/.

\section{References}

1. Ponikowski P, Voors AA, Anker SD, Bueno H, Cleland JGF, Coats AJS, Falk V, Gonzalez-Juanatey JR, Harjola VP, Jankowska EA, Jessup M, Linde C, Nihoyannopoulos P, Parissis JT, Pieske B, Riley JP, Rosano GMC, Ruilope LM, Ruschitzka F, Rutten FH, van der Meer P, Group ESCSD (2016) 2016 ESC guidelines for the diagnosis and treatment of acute and chronic heart failure: the task force for the diagnosis and treatment of acute and chronic heart failure of the European Society of Cardiology (ESC) developed with the special contribution of the Heart Failure Association (HFA) of the ESC. Eur Heart J 37(27):2129-2200. https://doi.org/10.1093/eurheartj/ehw128

2. Yancy CW, Jessup M, Bozkurt B, Butler J, Casey DE Jr, Colvin MM, Drazner MH, Filippatos GS, Fonarow GC, Givertz MM, Hollenberg SM, Lindenfeld J, Masoudi FA, McBride PE, Peterson PN, Stevenson LW, Westlake C (2017) 2017 ACC/ AHA/HFSA focused update of the 2013 ACCF/AHA guideline for the management of heart failure: a report of the American College of Cardiology/American Heart Association Task Force on Clinical Practice Guidelines and the Heart Failure Society of America. J Card Fail 23(8):628-651. https://doi.org/10.1016/j. cardfail.2017.04.014
3. Savarese G, Lund LH (2017) Global public health burden of heart failure. Card Fail Rev 3(1):7-11. https://doi.org/10.15420/cfr. 2016:25:2

4. Cowie MR, Wood DA, Coats AJ, Thompson SG, Suresh V, PooleWilson PA, Sutton GC (2000) Survival of patients with a new diagnosis of heart failure: a population based study. Heart 83(5): 505-510

5. Mosterd A, Cost B, Hoes AW, de Bruijne MC, Deckers JW, Hofman A, Grobbee DE (2001) The prognosis of heart failure in the general population: the Rotterdam study. Eur Heart J 22(15): 1318-1327. https://doi.org/10.1053/euhj.2000.2533

6. Rosamond W, Flegal K, Furie K, Go A, Greenlund K, Haase N, Hailpern SM, Ho M, Howard V, Kissela B, Kittner S, Lloyd-Jones D, McDermott M, Meigs J, Moy C, Nichol G, O'Donnell C, Roger V, Sorlie P, Steinberger J, Thom T, Wilson M, Hong Y, American Heart Association Statistics C, Stroke Statistics S (2008) Heart disease and stroke statistics-2008 update: a report from the American Heart Association Statistics Committee and Stroke Statistics Subcommittee. Circulation 117(4):e25-e146. https:// doi.org/10.1161/CIRCULATIONAHA.107.187998

7. Chun S, Tu JV, Wijeysundera HC, Austin PC, Wang X, Levy D, Lee DS (2012) Lifetime analysis of hospitalizations and survival of patients newly admitted with heart failure. Circ Heart Fail 5(4): 414-421. https://doi.org/10.1161/CIRCHEARTFAILURE.111. 964791

8. Bergethon KE, Ju C, DeVore AD, Hardy NC, Fonarow GC, Yancy CW, Heidenreich PA, Bhatt DL, Peterson ED, Hernandez AF (2016) Trends in 30-day readmission rates for patients hospitalized with heart failure. 9(6):e002594. https://doi.org/10.1161/ CIRCHEARTFAILURE.115.002594

9. Gheorghiade M, Abraham WT, Albert NM, Greenberg BH, O'Connor CM, She L, Stough WG, Yancy CW, Young JB, Fonarow GC, Investigators O-H, Coordinators (2006) Systolic blood pressure at admission, clinical characteristics, and outcomes in patients hospitalized with acute heart failure. JAMA 296(18): 2217-2226. https://doi.org/10.1001/jama.296.18.2217

10. Allen LA, Gheorghiade M, Reid KJ, Dunlay SM, Chan PS, Hauptman PJ, Zannad F, Konstam MA, Spertus JA (2011) Identifying patients hospitalized with heart failure at risk for unfavorable future quality of life. 4 (4):389-398. https://doi.org/10. 1161/CIRCOUTCOMES.110.958009

11. Kociol RD, Horton JR, Fonarow GC, Reyes EM, Shaw LK, O'Connor CM, Felker GM, Hernandez AF (2011) Admission, discharge, or change in B-type natriuretic peptide and long-term outcomes. 4(5):628-636. https://doi.org/10.1161/ CIRCHEARTFAILURE.111.962290

12. Masson S, Anand I, Favero C, Barlera S, Vago T, Bertocchi F, Maggioni AP, Tavazzi L, Tognoni G, Cohn JN, Latini R (2012) Serial measurement of cardiac troponin $\mathrm{T}$ using a highly sensitive assay in patients with chronic heart failure. 125(2):280-288. https://doi.org/10.1161/CIRCULATIONAHA.111.044149

13. Verbrugge FH, Steels P, Grieten L, Nijst P, Tang WHW, Mullens W (2015) Hyponatremia in acute decompensated heart failure. Depletion versus dilution. J Am Coll Cardiol 65(5):480-492. https://doi.org/10.1016/j.jacc.2014.12.010

14. Fujiu K, Shibata M, Nakayama Y, Ogata F, Matsumoto S, Noshita K, Iwami S, Nakae S, Komuro I, Nagai R, Manabe I (2017) A heart-brain-kidney network controls adaptation to cardiac stress through tissue macrophage activation. Nat Med 23(5):611-622. https://doi.org/10.1038/nm.4326

15. Kittleson M, Hurwitz S, Shah MR, Nohria A, Lewis E, Givertz M, Fang J, Jarcho J, Mudge G, Stevenson LW (2003) Development of circulatory-renal limitations to angiotensin-converting enzyme inhibitors identifies patients with severe heart failure and early mortality. J Am Coll Cardiol 41(11):2029-2035. https://doi.org/10. 1016/s0735-1097(03)00417-0 
16. Levy D, Larson MG, Vasan RS, Kannel WB, Ho KK (1996) The progression from hypertension to congestive heart failure. JAMA 275(20):1557-1562

17. Aronson D, Mittleman MA, Burger AJ (2004) Measures of heart period variability as predictors of mortality in hospitalized patients with decompensated congestive heart failure. Am J Cardiol 93(1): 59-63. https://doi.org/10.1016/j.amjcard.2003.09.013

18. Potpara TS, Polovina MM, Licina MM, Marinkovic JM, Lip GYH (2013) Predictors and prognostic implications of incident heart failure following the first diagnosis of atrial fibrillation in patients with structurally normal hearts: the Belgrade Atrial Fibrillation Study. 15(4):415-424. https://doi.org/10.1093/eurjhf/hft004

19. Rice MJ, Coursin DB (2016) Glucose meters: here today, gone tomorrow? 44(2):e97-e100. https://doi.org/10.1097/ccm. 0000000000001389

20. Kennedy HL (2013) The evolution of ambulatory ECG monitoring. Prog Cardiovasc Dis 56(2):127-132. https://doi.org/10.1016/ j.pcad.2013.08.005

21. Dorsey ER, Topol EJ (2016) State of telehealth. 375 (2):154-161. https://doi.org/10.1056/NEJMra1601705

22. Ferrante D, Varini S, Macchia A, Soifer S, Badra R, Nul D, Grancelli H, Doval H, Investigators G (2010) Long-term results after a telephone intervention in chronic heart failure: DIAL (randomized trial of phone intervention in chronic heart failure) follow-up. J Am Coll Cardiol 56(5):372-378. https://doi.org/10. 1016/j.jacc.2010.03.049

23. Koehler F, Winkler S, Schieber M, Sechtem U, Stang1 K, Böhm M, Boll H, Baumann G, Honold M, Koehler K, Gelbrich G, Kirwan B-A, Anker SD (2011) Impact of remote telemedical management on mortality and hospitalizations in ambulatory patients with chronic heart failure. 123(17):1873-1880. https://doi.org/10. 1161/CIRCULATIONAHA.111.018473

24. Koehler F, Koehler K, Deckwart O, Prescher S, Wegscheider K, Winkler S, Vettorazzi E, Polze A, Stangl K, Hartmann O, Marx A, Neuhaus P, Scherf M, Kirwan B-A, Anker SD (2018) Telemedical Interventional Management in Heart Failure II (TIM-HF2), a randomised, controlled trial investigating the impact of telemedicine on unplanned cardiovascular hospitalisations and mortality in heart failure patients: study design and description of the intervention. Eur J Heart Fail 20(10):1485-1493. https://doi.org/10.1002/ ejhf. 1300

25. Hindricks G, Taborsky M, Glikson M, Heinrich U, Schumacher B, Katz A, Brachmann J, Lewalter T, Goette A, Block M, Kautzner J, Sack S, Husser D, Piorkowski C, Søgaard P (2014) Implant-based multiparameter telemonitoring of patients with heart failure (INTIME): a randomised controlled trial. Lancet 384(9943):583-590. https://doi.org/10.1016/S0140-6736(14)61176-4

26. Abraham WT, Perl L (2017) Implantable hemodynamic monitoring for heart failure patients. J Am Coll Cardiol 70(3):389-398. https://doi.org/10.1016/j.jacc.2017.05.052

27. Abraham WT, Stevenson LW, Bourge RC, Lindenfeld JA, Bauman JG, Adamson PB (2016) Sustained efficacy of pulmonary artery pressure to guide adjustment of chronic heart failure therapy: complete follow-up results from the CHAMPION randomised trial. Lancet 387(10017):453-461. https://doi.org/ 10.1016/S0140-6736(15)00723-0

28. Adamson Philip B, Abraham William T, Stevenson Lynne W, Desai Akshay S, Lindenfeld J, Bourge Robert C, Bauman J (2016) Pulmonary artery pressure-guided heart failure management reduces 30-day readmissions. Circ Heart Fail 9(6): e002600. https://doi.org/10.1161/CIRCHEARTFAILURE.115. 002600

29. Kotb A, Cameron C, Hsieh S, Wells G (2015) Comparative effectiveness of different forms of telemedicine for individuals with heart failure (HF): a systematic review and network meta-analysis.
PLoS One 10(2):e0118681. https://doi.org/10.1371/journal.pone. 0118681

30. Zhu Y, Gu X, Xu C (2019) Effectiveness of telemedicine systems for adults with heart failure: a meta-analysis of randomized controlled trials. Heart Fail Rev 25:231-243. https://doi.org/10.1007/ s10741-019-09801-5

31. Chaudhry SI, Mattera JA, Curtis JP, Spertus JA, Herrin J, Lin Z, Phillips CO, Hodshon BV, Cooper LS, Krumholz HM (2010) Telemonitoring in patients with heart failure. N Engl J Med 363(24):2301-2309. https://doi.org/10.1056/NEJMoa1010029

32. Angermann Christiane E, Störk S, Gelbrich G, Faller H, Jahns R, Frantz S, Loeffler M, Ertl G (2012) Mode of action and effects of standardized collaborative disease management on mortality and morbidity in patients with systolic heart failure. Circ Heart Fail 5(1):25-35. https://doi.org/10.1161/CIRCHEARTFAILURE.111. 962969

33. Gronda E, Vanoli E, Sacchi S, Grassi G, Ambrosio G, Napoli C (2020) Risk of heart failure progression in patients with reduced ejection fraction: mechanisms and therapeutic options. Heart Fail Rev 25(2):295-303. https://doi.org/10.1007/s10741-019-09823-Z

34. Lewin J, Ledwidge M, O'Loughlin C, McNally C, McDonald K (2005) Clinical deterioration in established heart failure: what is the value of BNP and weight gain in aiding diagnosis? Eur J Heart Fail 7(6):953-957. https://doi.org/10.1016/j.ejheart.2005.06.003

35. Ong MK, Romano PS, Edgington S, Aronow HU, Auerbach AD, Black JT, De Marco T, Escarce JJ, Evangelista LS, Hanna B, Ganiats TG, Greenberg BH, Greenfield S, Kaplan SH, Kimchi A, Liu H, Lombardo D, Mangione CM, Sadeghi B, Sadeghi B, Sarrafzadeh M, Tong K, Fonarow GC, Better Effectiveness After Transition-Heart Failure Research G (2016) Effectiveness of remote patient monitoring after discharge of hospitalized patients with heart failure: the better effectiveness after transition - heart failure (BEAT-HF) randomized clinical trial. JAMA Intern Med 176(3):310-318. https://doi.org/10.1001/jamainternmed.2015. 7712

36. Pekmezaris R, Nouryan CN, Schwartz R, Castillo S, Makaryus AN, Ahern D, Akerman MB, Lesser ML, Bauer L, Murray L, Pecinka K, Zeltser R, Zhang M, DiMarzio P (2019) A randomized controlled trial comparing telehealth self-management to standard outpatient management in underserved Black and Hispanic patients living with heart failure. Telemed J E Health 25(10):917925. https://doi.org/10.1089/tmj.2018.0219

37. Maurizi N, Faragli A, Imberti J, Briante N, Targetti M, Baldini K, Sall A, Cisse A, Berzolari FG, Borrelli P, Avvantaggiato F, Perlini S, Marchionni N, Cecchi F, Parigi G, Olivotto I (2017) Cardiovascular screening in low-income settings using a novel 4-lead smartphone-based electrocardiograph (D-Heart(R)). Int J Cardiol 236:249-252. https://doi.org/10.1016/j.ijcard.2017.02. 027

38. Raja JM, Elsakr C, Roman S, Cave B, Pour-Ghaz I, Nanda A, Maturana M, Khouzam RN (2019) Apple watch, wearables, and heart rhythm: where do we stand? Ann Transl Med 7(17):417. https://doi.org/10.21037/atm.2019.06.79

39. DeVore AD, Wosik J, Hernandez AF (2019) The future of wearables in heart failure patients. JACC: Heart Fail 7(11):922-932. https://doi.org/10.1016/j.jchf.2019.08.008

40. Cleland JGF, Louis AA, Rigby AS, Janssens U, Balk AHMM (2005) Noninvasive home telemonitoring for patients with heart failure at high risk of recurrent admission and death: the TransEuropean Network-Home-Care Management System (TENHMS) study. J Am Coll Cardiol 45(10):1654-1664. https://doi. org/10.1016/j.jacc.2005.01.050

41. Villani A, Malfatto G, Compare A, Rosa FD, Bellardita L, Branzi G, Molinari E, Parati G (2014) Clinical and psychological telemonitoring and telecare of high risk heart failure patients. J 
Telemed Telecare 20(8):468-475. https://doi.org/10.1177/ $1357633 X 14555644$

42. Lang NN, Wong CM, Dalzell JR, Jansz S, Leslie SJ, Gardner RS (2014) The ease of use and reproducibility of the Alere ${ }^{\mathrm{TM}}$ Heart Check System: a comparison of patient and healthcare professional measurement of BNP. Biomark Med 8(6):791-796. https://doi. org $/ 10.2217 / \mathrm{bmm} .14 .48$

43. Maisel AS, Shah KS, Barnard D, Jaski B, Frivold G, Marais J, Azer M, Miyamoto MI, Lombardo D, Kelsay D, Iqbal N, Taub PR, Kupfer K, Lee E, Clopton P, Zile M, Greenberg B (2016) How B-type natriuretic peptide (BNP) and body weight changes vary in heart failure with preserved ejection fraction compared with reduced ejection fraction: secondary results of the HABIT (HF assessment with BNP in the home) trial. J Card Fail 22(4):283-293. https://doi.org/10.1016/j.cardfail.2015.09.014

44. Schwamm LH, Chumbler N, Brown E, Fonarow GC, Berube D, Nystrom K, Suter R, Zavala M, Polsky D, Radhakrishnan K, Lacktman N, Horton K, Malcarney M-B, Halamka J, Tiner AC (2017) Recommendations for the implementation of telehealth in cardiovascular and stroke care: a policy statement from the American Heart Association. 135(7):e24-e44. https://doi.org/10. 1161/CIR.0000000000000475

45. Abraham WT, Adamson PB, Bourge RC, Aaron MF, Costanzo MR, Stevenson LW, Strickland W, Neelagaru S, Raval N, Krueger S, Weiner S, Shavelle D, Jeffries B, Yadav JS (2011) Wireless pulmonary artery haemodynamic monitoring in chronic heart failure: a randomised controlled trial. Lancet 377(9766):658-666. https://doi.org/10.1016/S0140-6736(11)60101-3

46. Anker SD, Koehler F, Abraham WT (2011) Telemedicine and remote management of patients with heart failure. Lancet 378(9792):731-739. https://doi.org/10.1016/S0140-6736(11) 61229-4

47. Dickinson MG, Allen LA, Albert NA, DiSalvo T, Ewald GA, Vest AR, Whellan DJ, Zile MR, Givertz MM (2018) Remote monitoring of patients with heart failure: a white paper from the Heart Failure Society of America Scientific Statements Committee. J Card Fail 24(10):682-694. https://doi.org/10.1016/j.cardfail. 2018.08.011

48. Inglis S (2010) Structured telephone support or telemonitoring programmes for patients with chronic heart failure. J Evid-Based Med 3(4):228-228. https://doi.org/10.1111/j.1756-5391.2010. 01104.x

49. Inglis SC, Clark RA, McAlister FA, Stewart S, Cleland JGF (2011) Which components of heart failure programmes are effective? A systematic review and meta-analysis of the outcomes of structured telephone support or telemonitoring as the primary component of chronic heart failure management in 8323 patients: Abridged Cochrane Review. Eur J Heart Fail 13(9):1028-1040. https://doi.org/10.1093/eurjhf/hfr039

50. Inglis SC, Clark RA, Dierckx R, Prieto-Merino D, Cleland JG (2017) Structured telephone support or non-invasive telemonitoring for patients with heart failure. Heart 103(4):255257. https://doi.org/10.1136/heartjnl-2015-309191

51. Lin M-h, Yuan W-l, Huang T-c, Zhang H-f, Mai J-t, Wang J-f (2017) Clinical effectiveness of telemedicine for chronic heart failure: a systematic review and meta-analysis. J Investig Med 65(5):899-911. https://doi.org/10.1136/jim-2016-000199

52. Khalil SF, Mohktar MS, Ibrahim F (2014) The theory and fundamentals of bioimpedance analysis in clinical status monitoring and diagnosis of diseases. Sensors 14(6):10895-10928. https://doi. org/10.3390/s140610895

53. Wang L, Lahtinen S, Lentz L, Rakow N, Kaszas C, Ruetz L, Stylos L, Olson WH (2005) Feasibility of using an implantable system to measure thoracic congestion in an ambulatory chronic heart failure canine model. Pacing Clin Electrophysiol 28(5):404 411. https://doi.org/10.1111/j.1540-8159.2005.40009.x
54. Wang L (2007) Fundamentals of intrathoracic impedance monitoring in heart failure. Am J Cardiol 99(10A):3G-10G. https://doi. org/10.1016/j.amjcard.2007.02.009

55. van Veldhuisen DJ, Braunschweig F, Conraads V, Ford I, Cowie MR, Jondeau G, Kautzner J, Aguilera RM, Lunati M, Yu CM, Gerritse B, Borggrefe M, Investigators D-H (2011) Intrathoracic impedance monitoring, audible patient alerts, and outcome in patients with heart failure. Circulation 124(16):1719-1726. https:// doi.org/10.1161/CIRCULATIONAHA.111.043042

56. Anand IS, Tang WH, Greenberg BH, Chakravarthy N, Libbus I, Katra RP, Music I (2012) Design and performance of a multisensor heart failure monitoring algorithm: results from the multisensor monitoring in congestive heart failure (MUSIC) study. J Card Fail 18(4):289-295. https://doi.org/10.1016/j.cardfail. 2012.01.009

57. Dovancescu S, Saczynski JS, Darling CE, Riistama J, Sert Kuniyoshi F, Meyer T, Goldberg R, McManus DD (2015) Detecting heart failure decompensation by measuring transthoracic bioimpedance in the outpatient setting: rationale and design of the SENTINEL-HF study. JMIR Res Protoc 4(4):e121. https:// doi.org/10.2196/resprot.4899

58. Bruining N, Barendse R, Cummins P (2017) The future of computers in cardiology: 'the connected patient'? Eur Heart J 38(23): 1781-1794. https://doi.org/10.1093/eurheartj/ehx264

59. Cowie MR (2019) Exploring digital technology's potential for cardiology. Eur Heart J 40(28):2283-2284. https://doi.org/10. 1093/eurheartj/ehz490

60. Hale TM, Jethwani K, Kandola MS, Saldana F, Kvedar JC (2016) A remote medication monitoring system for chronic heart failure patients to reduce readmissions: a two-arm randomized pilot study. J Med Internet Res 18(4):e91. https://doi.org/10.2196/jmir. 5256

61. Ware P, Ross HJ, Cafazzo JA, Laporte A, Gordon K, Seto E (2018) Evaluating the implementation of a mobile phone-based telemonitoring program: longitudinal study guided by the consolidated framework for implementation research. JMIR Mhealth Uhealth 6(7):e10768. https://doi.org/10.2196/10768

62. Gingele AJ, Ramaekers B, Brunner-La Rocca HP, De Weerd G, Kragten J, van Empel V, van der Weg K, Vrijhoef HJM, Gorgels A, Cleuren G, Boyne JJJ, Knackstedt C (2019) Effects of tailored telemonitoring on functional status and health-related quality of life in patients with heart failure. Neth Hear J 27(11):565-574. https://doi.org/10.1007/s12471-019-01323-x

63. Chiauzzi E, Rodarte C, DasMahapatra P (2015) Patient-centered activity monitoring in the self-management of chronic health conditions. BMC Med 13(1):77. https://doi.org/10.1186/s12916-0150319-2

64. Thorup C, Hansen J, Grønkjær M, Andreasen JJ, Nielsen G, Sørensen EE, Dinesen BI (2016) Cardiac patients' walking activity determined by a step counter in cardiac telerehabilitation: data from the intervention arm of a randomized controlled trial. J Med Internet Res 18(4):e69. https://doi.org/10.2196/jmir.5191

65. Chan N-Y (2018) Systematic screening for atrial fibrillation in the community: evidence and obstacles. Arrhythm Electrophysiol Rev 7(1):39-42. https://doi.org/10.15420/aer.2017.47.2

66. Amir O, Ben-Gal T, Weinstein JM, Schliamser J, Burkhoff D, Abbo A, Abraham WT (2017) Evaluation of remote dielectric sensing (ReDS) technology-guided therapy for decreasing heart failure re-hospitalizations. Int J Cardiol 240:279-284. https://doi. org/10.1016/j.ijcard.2017.02.120

67. Inan OT, Baran Pouyan M, Javaid AQ, Dowling S, Etemadi M, Dorier A, Heller JA, Bicen AO, Roy S, De Marco T, Klein L (2018) Novel wearable seismocardiography and machine learning algorithms can assess clinical status of heart failure patients. Circ Heart Fail 11(1):e004313-e004313. https://doi.org/10.1161/ CIRCHEARTFAILURE.117.004313 
68. Gargani L, Frassi F, Soldati G, Tesorio P, Gheorghiade M, Picano E (2008) Ultrasound lung comets for the differential diagnosis of acute cardiogenic dyspnoea: a comparison with natriuretic peptides ¿ $^{2}$. Eur J Heart Fail 10(1):70-77. https://doi.org/10.1016/j. ejheart.2007.10.009

69. Platz E, Lattanzi A, Agbo C, Takeuchi M, Resnic FS, Solomon SD, Desai AS (2012) Utility of lung ultrasound in predicting pulmonary and cardiac pressures. Eur J Heart Fail 14(11):1276-1284. https://doi.org/10.1093/eurjhf/hfs144

70. Picano E, Scali MC, Ciampi Q, Lichtenstein D (2018) Lung ultrasound for the cardiologist. JACC Cardiovasc Imaging 11(11): 1692-1705. https://doi.org/10.1016/j.jcmg.2018.06.023

71. Picano E, Pellikka PA (2016) Ultrasound of extravascular lung water: a new standard for pulmonary congestion. Eur Heart J 37(27):2097-2104. https://doi.org/10.1093/eurheartj/ehw164

72. Mebazaa A, Yilmaz MB, Levy P, Ponikowski P, Peacock WF, Laribi S, Ristic AD, Lambrinou E, Masip J, Riley JP, McDonagh T, Mueller C, deFilippi C, Harjola V-P, Thiele H, Piepoli MF, Metra M, Maggioni A, McMurray J, Dickstein K, Damman K, Seferovic PM, Ruschitzka F, Leite-Moreira AF, Bellou A, Anker SD, Filippatos G (2015) Recommendations on pre-hospital \& early hospital management of acute heart failure: a consensus paper from the heart failure Association of the European Society of Cardiology, the European Society of Emergency Medicine and the Society of Academic Emergency Medicine. Eur J Heart Fail 17(6):544-558. https://doi.org/10. 1002/ejhf.289

73. Pivetta E, Goffi A, Nazerian P, Castagno D, Tozzetti C, Tizzani P, Tizzani M, Porrino G, Ferreri E, Busso V, Morello F, Paglieri C, Masoero M, Cassine E, Bovaro F, Grifoni S, Maule MM, Lupia E, on behalf of the Study Group on Lung Ultrasound from the M, Careggi H (2019) Lung ultrasound integrated with clinical assessment for the diagnosis of acute decompensated heart failure in the emergency department: a randomized controlled trial. Eur J Heart Fail 21(6):754-766. https://doi.org/10.1002/ejhf.1379

74. Pivetta E, Goffi A, Lupia E, Tizzani M, Porrino G, Ferreri E, Volpicelli G, Balzaretti P, Banderali A, Iacobucci A, Locatelli S, Casoli G, Stone MB, Maule MM, Baldi I, Merletti F, Cibinel GA, Baron P, Battista S, Buonafede G, Busso V, Conterno A, Del Rizzo P, Ferrera P, Pecetto PF, Moiraghi C, Morello F, Steri F, Ciccone G, Calasso C, Caserta MA, Civita M, Condo C, D'Alessandro V, Del Colle S, Ferrero S, Griot G, Laurita E, Lazzero A, Lo Curto F, Michelazzo M, Nicosia V, Palmari N, Ricchiardi A, Rolfo A, Rostagno R, Bar F, Boero E, Frascisco M, Micossi I, Mussa A, Stefanone V, Agricola R, Cordero G, Corradi F, Runzo C, Soragna A, Sciullo D, Vercillo D, Allione A, Artana N, Corsini F, Dutto L, Lauria G, Morgillo T, Tartaglino B, Bergandi D, Cassetta I, Masera C, Garrone M, Ghiselli G, Ausiello L, Barutta L, Bernardi E, Bono A, Forno D, Lamorte A, Lison D, Lorenzati B, Maggio E, Masi I, Maggiorotto M, Novelli G, Panero F, Perotto M, Ravazzoli M, Saglio E, Soardo F, Tizzani A, Tizzani P, Tullio M, Ulla M, Romagnoli E (2015) Lung ultrasound-implemented diagnosis of acute decompensated heart failure in the ED. CHEST 148(1):202-210. https://doi.org/ 10.1378/chest.14-2608

75. Platz E, Lewis EF, Uno H, Peck J, Pivetta E, Merz AA, Hempel D, Wilson C, Frasure SE, Jhund PS, Cheng S, Solomon SD (2016) Detection and prognostic value of pulmonary congestion by lung ultrasound in ambulatory heart failure patients. Eur Heart J 37(15): 1244-1251. https://doi.org/10.1093/eurheartj/ehv745

76. Gustafsson M, Alehagen U, Johansson P (2015) Imaging congestion with a pocket ultrasound device: prognostic implications in patients with chronic heart failure. J Card Fail 21(7):548-554. https://doi.org/10.1016/j.cardfail.2015.02.004

77. Palazzuoli A, Ruocco G, Beltrami M, Nuti R, Cleland JG (2018) Combined use of lung ultrasound, B-type natriuretic peptide, and echocardiography for outcome prediction in patients with acute HFrEF and HFpEF. Clin Res Cardiol 107(7):586-596. https:// doi.org/10.1007/s00392-018-1221-7

78. Rivas-Lasarte M, Álvarez-García J, Fernández-Martínez J, Maestro A, López-López L, Solé-González E, Pirla MJ, Mesado N, Mirabet S, Fluvià P, Brossa V, Sionis A, Roig E, Cinca J (2019) Lung ultrasound-guided treatment in ambulatory patients with heart failure: a randomized controlled clinical trial (LUS-HF study). Eur J Heart Fail 21(12):1605-1613. https://doi.org/10. 1002/ejhf.1604

79. Platz E, Solomon SD, McMurray JJV (2019) Lung ultrasound: monitoring congestion in patients with heart failure. Eur J Heart Fail 21(12):1614-1615. https://doi.org/10.1002/ejhf.1636

80. Peters MN, deFilippi CR (2016) Natriuretic peptide guided therapy in outpatient heart failure management. In: Maisel AS, Jaffe AS (eds) Cardiac biomarkers: case studies and clinical correlations. Springer International Publishing, Cham, pp 215-225. https://doi. org/10.1007/978-3-319-42982-3 18

81. Shah SP, Shah SP, Fils-Aime R, Desir W, Joasil J, Venesy DM, Muruganandan KM (2016) Focused cardiopulmonary ultrasound for assessment of dyspnea in a resource-limited setting. Crit Ultrasound J 8(1):7. https://doi.org/10.1186/s13089-016-0043-y

82. Gundersen GH, Norekvål TM, Graven T, Haug HH, Skjetne K, Kleinau JO, Gustad LT, Dalen H (2017) Patient-reported outcomes and associations with pleural effusion in outpatients with heart failure: an observational cohort study. BMJ Open 7(3): e013734. https://doi.org/10.1136/bmjopen-2016-013734

83. Gundersen GH, Norekval TM, Haug HH, Skjetne K, Kleinau JO, Graven T, Dalen H (2016) Adding point of care ultrasound to assess volume status in heart failure patients in a nurse-led outpatient clinic. A randomised study. Heart 102(1):29-34. https://doi. org/10.1136/heartjnl-2015-307798

84. Januzzi JL Jr, Sakhuja R, O’Donoghue M, Baggish AL, Anwaruddin S, Chae CU, Cameron R, Krauser DG, Tung R, Camargo CA Jr, Lloyd-Jones DM (2006) Utility of aminoterminal pro-brain natriuretic peptide testing for prediction of 1year mortality in patients with dyspnea treated in the emergency department. Arch Intern Med 166(3):315-320. https://doi.org/10. 1001/archinte.166.3.315

85. Anand IS, Fisher LD, Chiang Y-T, Latini R, Masson S, Maggioni AP, Glazer RD, Tognoni G, Cohn JN (2003) Changes in brain natriuretic peptide and norepinephrine over time and mortality and morbidity in the valsartan heart failure trial (Val-HeFT). 107(9):1278-1283. https://doi.org/10.1161/01.CIR.0000054164. 99881.00

86. Pfisterer M, Buser P, Rickli H, Gutmann M, Erne P, Rickenbacher P, Vuillomenet A, Jeker U, Dubach P, Beer H, Yoon S-I, Suter T, Osterhues HH, Schieber MM, Hilti P, Schindler R, Brunner-La Rocca H-P, TIME-CHF Investigators ft (2009) BNP-Guided vs symptom-guided heart failure therapy: the trial of intensified vs standard medical therapy in elderly patients with congestive heart failure (TIME-CHF) randomized trial. JAMA 301(4):383-392. https://doi.org/10.1001/jama.2009.2

87. Brunner-La Rocca H-P, Sanders-van Wijk S (2019) Natriuretic peptides in chronic heart failure. Cardiac failure review. 5(1):44 49. https://doi.org/10.15420/cfr.2018.26.1

88. Troughton RW, Frampton CM, Brunner-La Rocca H-P, Pfisterer M, Eurlings LWM, Erntell H, Persson H, O'Connor CM, Moertl D, Karlström P, Dahlström U, Gaggin HK, Januzzi JL, Berger R, Richards AM, Pinto YM, Nicholls MG (2014) Effect of B-type natriuretic peptide-guided treatment of chronic heart failure on total mortality and hospitalization: an individual patient meta-analysis. Eur Heart J 35(23):1559-1567. https://doi.org/10.1093/ eurheartj/ehu090

89. Felker GM, Anstrom KJ, Adams KF, Ezekowitz JA, Fiuzat M, Houston-Miller N, Januzzi JL Jr, Mark DB, Piña IL, Passmore G, 
Whellan DJ, Yang H, Cooper LS, Leifer ES, Desvigne-Nickens P, O'Connor CM (2017) Effect of natriuretic peptide-guided therapy on hospitalization or cardiovascular mortality in high-risk patients with heart failure and reduced ejection fraction: a randomized clinical trial. JAMA 318(8):713-720. https://doi.org/10.1001/ jama.2017.10565

90. Stienen S, Salah K, Moons AH, Bakx AL, Pol PV, Kortz RAM, Ferreira JP, Marques I, Schroeder-Tanka JM, Keijer JT, BayésGenis A, Tijssen JGP, Pinto YM, Kok WE (2018) NT-proBNP (N-terminal pro-B-type natriuretic peptide)-guided therapy in acute decompensated heart failure. 137(16):1671-1683. https:// doi.org/10.1161/CIRCULATIONAHA.117.029882

91. McDonald K, Troughton R, Dahlström U, Dargie H, Krum H, van der Meer P, McDonagh T, Atherton JJ, Kupfer K, San George RC, Richards M, Doughty R (2018) Daily home BNP monitoring in heart failure for prediction of impending clinical deterioration: results from the HOME HF study. 20(3):474-480. https://doi. org/10.1002/ejhf. 1053

92. Maisel A, Barnard D, Jaski B, Frivold G, Marais J, Azer M, Miyamoto MI, Lombardo D, Kelsay D, Borden K, Iqbal N, Taub PR, Kupfer K, Clopton P, Greenberg B (2013) Primary results of the HABIT trial (heart failure assessment with BNP in the home). J Am Coll Cardiol 61(16):1726-1735. https://doi.org/10. 1016/j.jacc.2013.01.052

93. McDonald K, Troughton R, Dahlström U, Dargie H, Krum H, van der Meer P, McDonagh T, Atherton JJ, Kupfer K, San George RC, Richards M, Doughty R (2018) Daily home BNP monitoring in heart failure for prediction of impending clinical deterioration: results from the HOME HF study. Eur J Heart Fail 20(3):474 480. https://doi.org/10.1002/ejhf.1053

94. Inglis SC, Conway A, Cleland JGF, Clark RA (2014) Is age a factor in the success or failure of remote monitoring in heart failure? Telemonitoring and structured telephone support in elderly heart failure patients. Eur J Cardiovasc Nurs 14(3):248-255. https://doi.org/10.1177/1474515114530611

95. Ware P, Dorai M, Ross HJ, Cafazzo JA, Laporte A, Boodoo C, Seto E (2019) Patient adherence to a mobile phone-based heart failure telemonitoring program: a longitudinal mixed-methods study. JMIR mHealth and uHealth 7(2):e13259-e13259. https:// doi.org/10.2196/13259

96. Blum K, Gottlieb SS (2007) Morbidity and mortality benefits of reliable instrumental support. J Card Fail 13(6):S164. https://doi. org/10.1016/j.cardfail.2007.06.581

97. Dendale P, De Keulenaer G, Troisfontaines P, Weytjens C, Mullens W, Elegeert I, Ector B, Houbrechts M, Willekens K, Hansen D (2012) Effect of a telemonitoring-facilitated collaboration between general practitioner and heart failure clinic on mortality and rehospitalization rates in severe heart failure: the TEMA-HF 1 (TElemonitoring in the MAnagement of Heart Failure) study. Eur J Heart Fail 14(3):333-340. https://doi.org/ 10.1093/eurjhf/hfr144

98. Testani JM, Brisco MA, Kociol RD, Jacoby D, Bellumkonda L, Parikh CR, Coca SG, Tang WHW (2015) Substantial discrepancy between fluid and weight loss during acute decompensated heart failure treatment. Am J Med 128(7):776-783.e774. https://doi. org/10.1016/j.amjmed.2014.12.020

99. Seto E (2008) Cost comparison between telemonitoring and usual care of heart failure: a systematic review. Telemed e-Health 14(7): 679-686. https://doi.org/10.1089/tmj.2007.0114

100. Blum K, Gottlieb SS (2014) The effect of a randomized trial of home telemonitoring on medical costs, 30-day readmissions, mortality, and health-related quality of life in a cohort of communitydwelling heart failure patients. J Card Fail 20(7):513-521
101. Klersy C, De Silvestri A, Gabutti G, Raisaro A, Curti M, Regoli F, Auricchio A (2011) Economic impact of remote patient monitoring: an integrated economic model derived from a meta-analysis of randomized controlled trials in heart failure. Eur J Heart Fail 13(4):450-459. https://doi.org/10.1093/eurjhf/hfq232

102. Nakamura N, Koga T, Iseki H (2013) A meta-analysis of remote patient monitoring for chronic heart failure patients. J Telemed Telecare 20(1):11-17. https://doi.org/10.1177/ $1357633 X 13517352$

103. Stamp KD, Prasun M, Lee CS, Jaarsma T, Piano MR, Albert NM (2018) Nursing research in heart failure care: a position statement of the American association of heart failure nurses (AAHFN). Heart Lung 47(2):169-175. https://doi.org/10.1016/j.hrtlng.2018. 01.003

104. Coen J, Curry K (2016) Improving heart failure outcomes: the role of the clinical nurse specialist. Crit Care Nurs Q 39(4):335-344. https://doi.org/10.1097/CNQ.0000000000000127

105. Seferovic PM, Ponikowski P, Anker SD, Bauersachs J, Chioncel O, Cleland JGF, de Boer RA, Drexel H, Ben Gal T, Hill L, Jaarsma T, Jankowska EA, Anker MS, Lainscak M, Lewis BS, McDonagh T, Metra M, Milicic D, Mullens W, Piepoli MF, Rosano G, Ruschitzka F, Volterrani M, Voors AA, Filippatos G, Coats AJS (2019) Clinical practice update on heart failure 2019: pharmacotherapy, procedures, devices and patient management. An expert consensus meeting report of the Heart Failure Association of the European Society of Cardiology. Eur J Heart Fail 21(10):1169 1186. https://doi.org/10.1002/ejhf.1531

106. Xiang R, Li L, Liu SX (2013) Meta-analysis and meta-regression of telehealth programmes for patients with chronic heart failure. J Telemed Telecare 19(5):249-259. https://doi.org/10.1177/ 1357633 X13495490

107. Kitsiou S, Paré G, Jaana M (2015) Effects of home telemonitoring interventions on patients with chronic heart failure: an overview of systematic reviews. J Med Internet Res 17(3):e63-e63. https://doi. org/10.2196/jmir.4174

108. Coppini LZ, Waitzberg DL, Campos ACL (2005) Limitations and validation of bioelectrical impedance analysis in morbidly obese patients. 8(3):329-332. https://doi.org/10.1097/01.mco. 0000165013.54696 .64

109. Roehrich L, Knierim J, Hajduczenia M, Mulzer J, Mueller M, Pergantis P, Hummel M, Falk V, Potapov E, Suendermann S, Schoenrath F (2019) Early- and late-onset arrhythmias after bioelectrical impedance analysis in end-stage heart failure patients under inotropic support. J Heart Lung Transplant 38(4):S377. https://doi.org/10.1016/j.healun.2019.01.958

110. Buch E, Bradfield J, Larson T, Horwich T (2012) Effect of bioimpedance body composition analysis on function of implanted cardiac devices. Pacing Clin Electrophysiol 35(6):681684. https://doi.org/10.1111/j.1540-8159.2012.03377.x

111. Chabin X, Taghli-Lamallem O, Mulliez A, Bordachar P, Jean F, Futier E, Massoullié G, Andonache M, Souteyrand G, Ploux S, Boirie Y, Richard R, Citron B, Lusson J-R, Godet T, Pereira B, Motreff P, Clerfond G, Eschalier R (2019) Bioimpedance analysis is safe in patients with implanted cardiac electronic devices. Clin Nutr 38(2):806-811. https://doi.org/10.1016/j.clnu.2018.02.029

112. Cleland JG, Antony R (2011) It makes SENSE to take a safer road. Eur Heart J 32(18):2225-2227. https://doi.org/10.1093/eurheartj/ ehr120

Publisher's note Springer Nature remains neutral with regard to jurisdictional claims in published maps and institutional affiliations. 